\title{
Country-scale greenhouse gas budgets using shipborne measurements: a case study for the UK and Ireland
}

\author{
Carole Helfter $^{1}$, Neil Mullinger ${ }^{1}$, Massimo Vieno ${ }^{1}$, Simon O’Doherty ${ }^{2}$, Michel Ramonet ${ }^{3}$, Paul I. Palmer ${ }^{4}$, and \\ Eiko Nemitz ${ }^{1}$ \\ ${ }^{1}$ Atmospheric Chemistry and Effects, Centre for Ecology and Hydrology, Penicuik, UK \\ ${ }^{2}$ School of Chemistry, University of Bristol, Bristol, UK \\ ${ }^{3}$ Laboratoire des Sciences du Climat et de l'Environnement, CEA-CNRS-UVSQ, Gif-sur-Yvette, France \\ ${ }^{4}$ School of GeoSciences, University of Edinburgh, Edinburgh, UK
}

Correspondence: Carole Helfter (caro2@ceh.ac.uk)

Received: 7 September 2018 - Discussion started: 1 October 2018

Revised: 22 February 2019 - Accepted: 25 February 2019 - Published: 11 March 2019

\begin{abstract}
We present a mass balance approach to estimate the seasonal and annual budgets of carbon dioxide $\left(\mathrm{CO}_{2}\right)$ and methane $\left(\mathrm{CH}_{4}\right)$ of the United Kingdom (excluding Scotland) and the Republic of Ireland from concentration measurements taken on a ferry along the east coast of the United Kingdom over a 3-year period (2015-2017). We estimate the annual emissions of $\mathrm{CH}_{4}$ to be $2.55 \pm 0.48 \mathrm{Tg}$, which is consistent with the combined 2.29 Tg reported to the United Nations Framework Convention on Climate Change by the individual countries. The net $\mathrm{CO}_{2}$ budget (i.e. including all anthropogenic and biogenic sources and sinks of $\mathrm{CO}_{2}$ ) is estimated at $881.0 \pm 125.8 \mathrm{Tg}$, with a net biogenic contribution of $458.7 \mathrm{Tg}$ (taken as the difference between the estimated net emissions and the inventory value, which accounts for anthropogenic emissions only). The largest emissions for both gases were observed in a broad latitudinal band (52.5$54^{\circ} \mathrm{N}$ ), which coincides with densely populated areas. The emissions of both gases were seasonal (maxima in winter and minima in summer), strongly correlated with natural gas usage and, to a lesser extent, also anti-correlated with mean air temperature. Methane emissions exhibited a statistically significant anti-correlation with air temperature at the seasonal timescale in the central region spanning $52.8-54.2^{\circ} \mathrm{N}$, which hosts a relatively high density of waste treatment facilities. Methane emissions from landfills have been shown to sometimes increase with decreasing air temperature due to changes in the $\mathrm{CH}_{4}$-oxidising potential of the topsoil, and we speculate that the waste sector contributes significantly to the $\mathrm{CH}_{4}$ budget of this central region. This study brings inde-
\end{abstract}

pendent verification of the emission budgets estimated using alternative products (e.g. mass balance budgets by aircraft measurements, inverse modelling, inventorying) and offers an opportunity to investigate the seasonality of these emissions, which is usually not possible.

\section{Introduction}

The United Nations Framework Convention on Climate Change (UNFCCC) kick-started an international political drive to reduce emissions of greenhouse gases (GHGs) and stabilise their midterm to long-term impact on the global climate. The focus of the international community over the past $2-3$ decades has been on curbing emissions of carbon dioxide $\left(\mathrm{CO}_{2}\right)$, the most abundant and well-understood GHG, but it is now recognised that emissions of other GHGs such as methane $\left(\mathrm{CH}_{4}\right)$ and nitrous oxide $\left(\mathrm{N}_{2} \mathrm{O}\right)$ must also be addressed in order to fulfil the goal of limiting irreversible climate change set out under the 21st Convention of Parties (COP21). Reductions in $\mathrm{CH}_{4}$ emissions in particular would be effective in reducing GHGs more quickly, given its shorter lifetime. Annex 1 parties are required to report their GHG inventories annually to the UNFCCC following the guidelines set out by the Intergovernmental Panel on Climate Change (IPCC, 2006; UNFCCC, 2014). Emissions inventories are powerful tools but they intrinsically rely on detailed knowledge of source abundance and strength, and they can therefore carry significant uncertainties. For example, uncertain- 


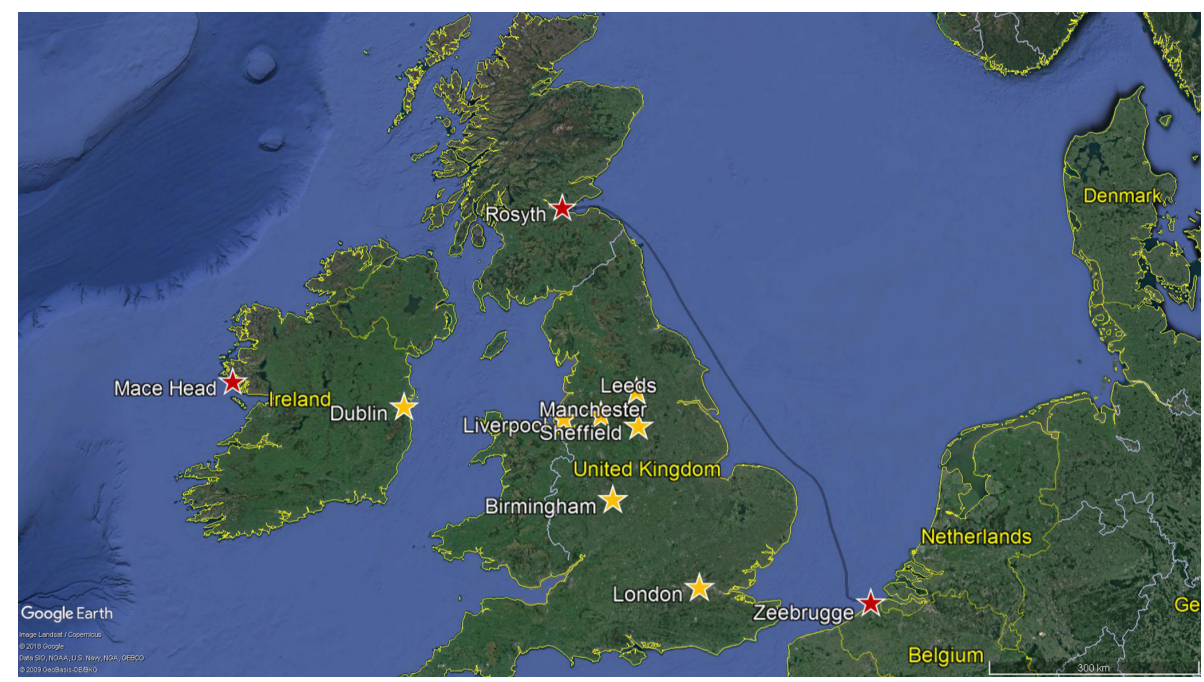

Figure 1. Google Earth map centred on the United Kingdom and Ireland. The route of the ferry is indicated by a dark blue line joining the ports of Rosyth (Scotland, UK) and Zeebrugge (Belgium). The location of the Mace Head measurement station on the west coast of Ireland, which provided the carbon dioxide and methane concentration baselines, is indicated by a red star. The cities indicated by yellow stars are locations of interest cited in the Discussion (Sect. 4).

ties on the fossil fuel emissions from Europe and North America have been estimated to be of the order of $2 \%$ to $5 \%$ (Marland, 2012); in contrast, a $1.4 \mathrm{Gt}$ gap in $\mathrm{CO}_{2}$ emissions was reported in China in 2010, which was equivalent to $\sim 5 \%$ of the global budget (Guan et al., 2012). Because much of its emission is directly linked to the amount of fossil fuel used, $\mathrm{CO}_{2}$ is the best-understood GHG but, despite this, regional and consequently global emissions budgets are thought to be underestimated and the uncertainties are increasing due to growing emissions from emerging economies (Gregg, 2008; Gregg et al., 2008; Peters et al., 2011). By contrast, relatively more $\mathrm{CH}_{4}$ emission is mediated by biological processes. After a period of stagnation in the first few years of the 21 st century, atmospheric $\mathrm{CH}_{4}$ has been rising steadily since ca. 2007. This prompted renewed efforts by the international scientific community to identify the drivers of $\mathrm{CH}_{4}$ at local, regional, and global scales and reconcile bottom-up and top-down estimates (Kirschke et al., 2013; Saunois et al., 2016). At the global scale, total methane emissions from fossil fuels (from the fossil fuel industry and from geological seepage) have been relatively steady over the past 3 decades, but research indicates that the estimates must be revised upwards by as much as $60 \%-110 \%$ (Schwietzke et al., 2016). Several mechanisms have been proposed to explain the recent rise in atmospheric methane; these include increases in emissions from microbial sources, which are meteorologically driven and can therefore exhibit substantial interannual variability (Dlugokencky et al., 2011; Nisbet et al., 2016; Schwietzke et al., 2016), a weakening of the hydroxyl (OH) chemical sink strength (Rigby et al., 2017; Turner et al., 2017), and an increase in fossil fuel contributions in the context of a stable $\mathrm{OH}$ sink and a downward revision of the biomass burning budget term (Worden et al., 2017). Inventories are thought to overestimate global emissions, and a difference of $130 \mathrm{Tg} \mathrm{CH}_{4} \mathrm{yr}^{-1}$ was found between bottom-up and top-down estimates (Kirschke et al., 2013). In this light, it is becoming increasingly clear that there is an urgent need to seek independent validation of the emissions inventories using an integrated range of measurements and modelling activities (Allen, 2016; Nisbet and Weiss, 2010).

The development in recent years of rugged, high-precision spectroscopic instruments (e.g. Peltola et al., 2014) has opened up new opportunities for continuous in situ measurements of methane at fine temporal resolution and at relatively large spatial scales. For example, such sensors have been used in airborne applications to study methane emissions from cities (Cambaliza et al., 2014, 2015; Mays et al., 2009; O'Shea et al., 2014) as well as anthropogenic and biogenic area sources (Hiller et al., 2014; Karion et al., 2013, 2015). Applications of eddy covariance to measure emission-deposition directly at the field scale are on the rise in a broad variety of environments ranging from agricultural and wetlands (Dengel et al., 2011; Erkkila et al., 2018; Felber et al., 2015; Meijide et al., 2011; Peltola et al., 2015; Podgrajsek et al., 2014; Nicolini et al., 2013) to urban (Gioli et al., 2012; Helfter et al., 2011, 2016; Pawlak and Fortuniak, 2016; Pawlak et al., 2016). Finally, networks of tall towers and networks thereof exist around the world to monitor and model methane emissions at spatial scales ranging from country to global (Bakwin et al., 1995; Bohnenstengel et al., 2015; Feng et al., 2009, 2011; Miller et al., 2013; Oney et al., 2015; Rigby et al., 2008; Stanley et al., 2018; Stavert et al., 2018). 
The geography of the British Isles at the NE edge of Europe, with dominantly SW winds advecting clean Atlantic air masses, particularly lends itself to a further approach, namely boundary layer budget measurements of concentrations in the inflow and outflow. This has previously been utilised for airborne boundary layer budget measurements (Fowler et al., 1996; Gallagher et al., 1994; Polson et al., 2011), but these can only provide snapshots of the country emissions for a few individual days.

Extending the concept of these earlier studies, we present 3 years of continuous observations (2015-2017) of $\mathrm{CO}_{2}$ and $\mathrm{CH}_{4}$ concentrations measured on board a commercial freight ferry, which connects the ports of Rosyth (Scotland, UK) to Zeebrugge (Belgium) and tracks the east coast of most of Great Britain (Fig. 1). The route of the ferry transects the UK outflow with a time-dependent footprint (Fig. 2), which, combined with a typical west-to-east air mass travel time of 11 to $19 \mathrm{~h}$ across the domain (median values for winter and summer, respectively), allows for sub-daily emissions estimations. Furthermore, the three continuous years of measurements also provide an opportunity to study seasonal and inter-annual changes in emissions. This is to our knowledge the first example of country-scale emission budgets using a mobile platform measuring continuously over several years.

These shipborne measurements formed part of a larger observation and modelling programme - the Greenhouse gAs Uk and Global Emissions (GAUGE) project (Palmer et al., 2018) - aimed at determining the magnitude, spatial distribution, and uncertainties of the UK's GHG budgets of $\mathrm{CO}_{2}$, $\mathrm{CH}_{4}$, and $\mathrm{N}_{2} \mathrm{O}$. In this paper we utilise shipborne observations at the outflow of the United Kingdom coupled with background measurements at the Mace Head site (Ireland) to estimate seasonal and annual budgets of $\mathrm{CO}_{2}$ and $\mathrm{CH}_{4}$ using a mass balance approach.

\section{Materials and methods}

This section describes the measurement systems used at the two experimental sites (Mace Head and ferry) and provides details of the greenhouse gas budget calculations and mass balance approach.

\subsection{Experimental set-up}

\subsubsection{Shipborne measurements}

Measurements of concentrations of carbon dioxide $\left(\mathrm{CO}_{2}\right)$ and methane $\left(\mathrm{CH}_{4}\right)$ began in February 2014 on board a commercial freight ferry (operated by DFDS Seaways) which served the route between Rosyth (Scotland, UK; $56^{\circ} 1^{\prime} 21.611^{\prime \prime} \mathrm{N}, 3^{\circ} 26^{\prime} 21.558^{\prime \prime} \mathrm{W}$ ) and Zeebrugge (Belgium; $\left.51^{\circ} 21^{\prime} 16.96^{\prime \prime} \mathrm{N}, 3^{\circ} 10^{\prime} 34.645^{\prime \prime} \mathrm{E}\right)$. The route of the ship followed the outline of the English coast on the east side of the UK, which placed it downwind of Atlantic air masses blowing in from the west over Ireland, Wales, and England
(Figs. 2 and 3). The ship completed three return journeys per week and typically operated for 48 weeks per calendar year. The schedule of the weekly cruises allowed for the latitude range to be sampled at different times of day and night as illustrated in Fig. 4.

The roll-on-roll-off (Ro-Ro) cargo-container carrier vessel Finnmerchant (former name Longstone; IMO: 9234082; overall length and breadth: $193 \mathrm{~m} \times 26 \mathrm{~m}$ ) served the Rosyth-Zeebrugge route during the measurement period 25 February-15 April 2014. It was replaced by the Ro-Ro cargo ship Finlandia Seaways (IMO: 9198721; overall length and breadth: $163 \mathrm{~m} \times 21 \mathrm{~m}$ ) on 15 June 2014 and measurement restarted aboard the new vessel.

Air was sampled on the topmost platform of the bow (port side on Finnmerchant and starboard side on Finlandia Seaways) and analysed by a cavity ring-down spectrometer (CRDS; Picarro 1301) housed in an air-conditioned measurement container located on the weather deck. Air was pumped at ca. $50 \mathrm{~L} \mathrm{~min}^{-1}$ through 20 and $50 \mathrm{~m}$ of $1 / 2^{\prime \prime}$ Synflex tubing at approximate measurement heights of $20 \mathrm{~m}$ and $30 \mathrm{~m}$ a.s.1. (on Finnmerchant and Finlandia Seaways, respectively) and subsampled at ca. $10 \mathrm{~L} \mathrm{~min}^{-1}$ through $2 \mathrm{~m}$ of $1 / 2^{\prime \prime}$ Synflex tube by a secondary pump. The subsampling $\mathrm{T}$ piece was set up as a virtual impactor to prevent moisture and sea salt from entering the CRDS sampling line, and the main sampling line was protected from moisture ingress by three water traps arranged in series (at the ambient air inlet point as well as immediately upstream and downstream of the virtual impactor).

The gas measurement system was equipped with a bespoke auto-calibration system controlled by an in-house LabView ${ }^{\mathrm{TM}}$ programme, which also handled the acquisition of data $(0.5 \mathrm{~Hz})$ from the Picarro gas analyser, a weather station (WXT520, Vaisala) co-located with the air inlet on the ship's top deck, and a GPS $(18 \times$ series, Garmin) receiver affixed to the roof of the sea container. Calibrations using three gases spanning a realistic range of $\mathrm{CO}_{2}$ and $\mathrm{CH}_{4}$ concentrations ran every $169 \mathrm{~h}$ and lasted $65 \mathrm{~min}$ in total. The references gases were calibrated by the Swiss Federal Laboratories for Materials Testing and Research (EMPA; Dübendorf, Switzerland) using a Picarro 1301 CRDS. The calibration scales (NOAA/ESRL) were WMO-CH4-X2004 for methane and $\mathrm{WMO}-\mathrm{CO}_{2}-\mathrm{X} 2007$ for carbon dioxide. Each gas standard was measured at $1 \mathrm{~Hz}$ for $15 \mathrm{~min}$, and the average and standard deviation were derived for the $15 \mathrm{~min}$ period. A 5 min purge period using the gas standard to be measured was observed before each active averaging period to flush out residual gas and eliminate sample contamination. Each calibration event ended with a 5 min purge period using ambient air before resuming normal operations. The gas concentration time series were corrected using linear temporal interpolations between calibration events. Table 1 provides a list of observables; Table 2 summarises the weekly auto-calibration procedure and provides information on the three calibration gases used. 


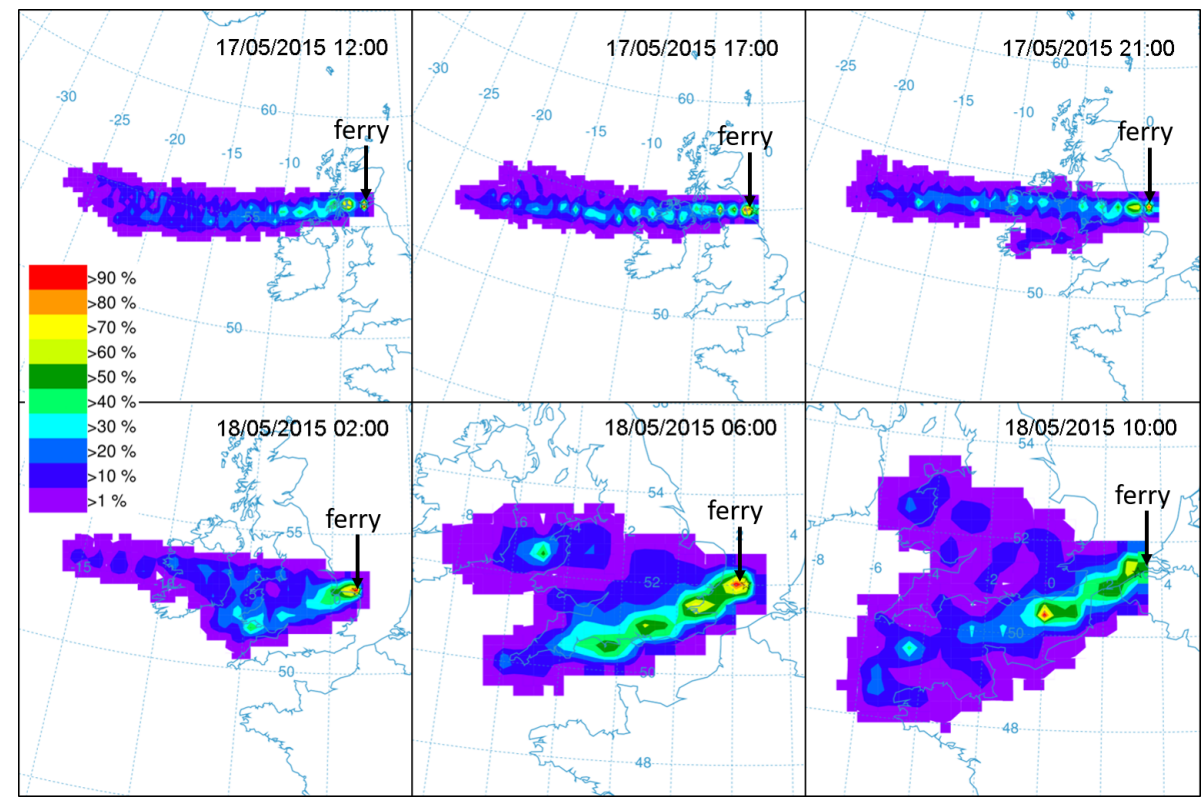

Figure 2. Backward trajectory frequencies for a south-bound sailing with westerly wind conditions (sailing start 17 May 2015 12:00, end 18 May 2015 10:00). The coloured contours represent the normalised frequency counts (number of end points in a $0.5^{\circ} \times 0.5^{\circ}$ grid cell divided by the maximum number of end points in any grid cell, expressed as a percentage) and the source corresponds to the location of the ferry (indicated by an arrow). The trajectories were run backward for $24 \mathrm{~h}$ at $3 \mathrm{~h}$ intervals using GDAS $1^{\circ}$ global meteorology (NOAA, 2018).
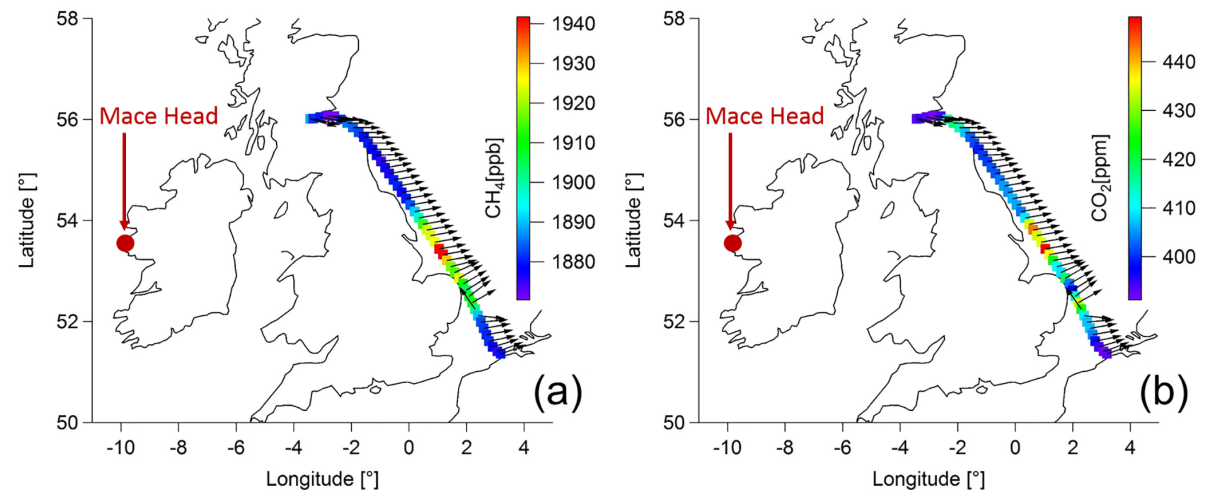

Figure 3. Half-hourly averages of (a) $\mathrm{CH}_{4}$ and (b) $\mathrm{CO}_{2}$ mole fractions measured on board the freight ferry during the south-bound journey on 29-30 July 2014. The arrows represent wind direction.

\subsubsection{Mace Head site}

The Mace Head station is located on the west coast of Ireland at $53^{\circ} 20^{\prime} \mathrm{N}, 9^{\circ} 54^{\prime} \mathrm{W}, 5 \mathrm{~m}$ a.s.l., and a $23 \mathrm{~m}$ high tower is used to sample the air. Atmospheric concentrations of $\mathrm{CO}_{2}$ have been continuously monitored at Mace Head since 1992 (Biraud et al., 2000; Derwent et al., 2002; Ramonet et al., 2010). Since 2010 a cavity ring-down spectrometer similar to the one used on board the ship (Picarro, G1301) has been used for $\mathrm{CO}_{2}$ and $\mathrm{CH}_{4}$ measurements (instrument owned by the Environment Protection Agency (EPA), Ireland). A second CRDS analyser (Picarro, G2301) was installed in 2013 (instrument owned by Laboratoire des Sciences du Climat et de l'Environnement (LSCE), France) to ensure the redundancy of measurements, thus reducing data gaps. Both analysers are calibrated simultaneously every month using a suite of four calibration cylinders whose concentrations span the atmospheric range. Those cylinders have themselves been calibrated at LSCE with WMO/NOAA reference scales (WMO2007 scale for $\mathrm{CO}_{2}$, WMO2004A scale for $\mathrm{CH}_{4}$ ). In addition to the calibration cylinders, two target cylinders are regularly analysed (short-term target twice a day and long-term target once a month) in order to assess measurement repeatability. Over the period 2014-2018 the difference between the assigned values and the values measured 


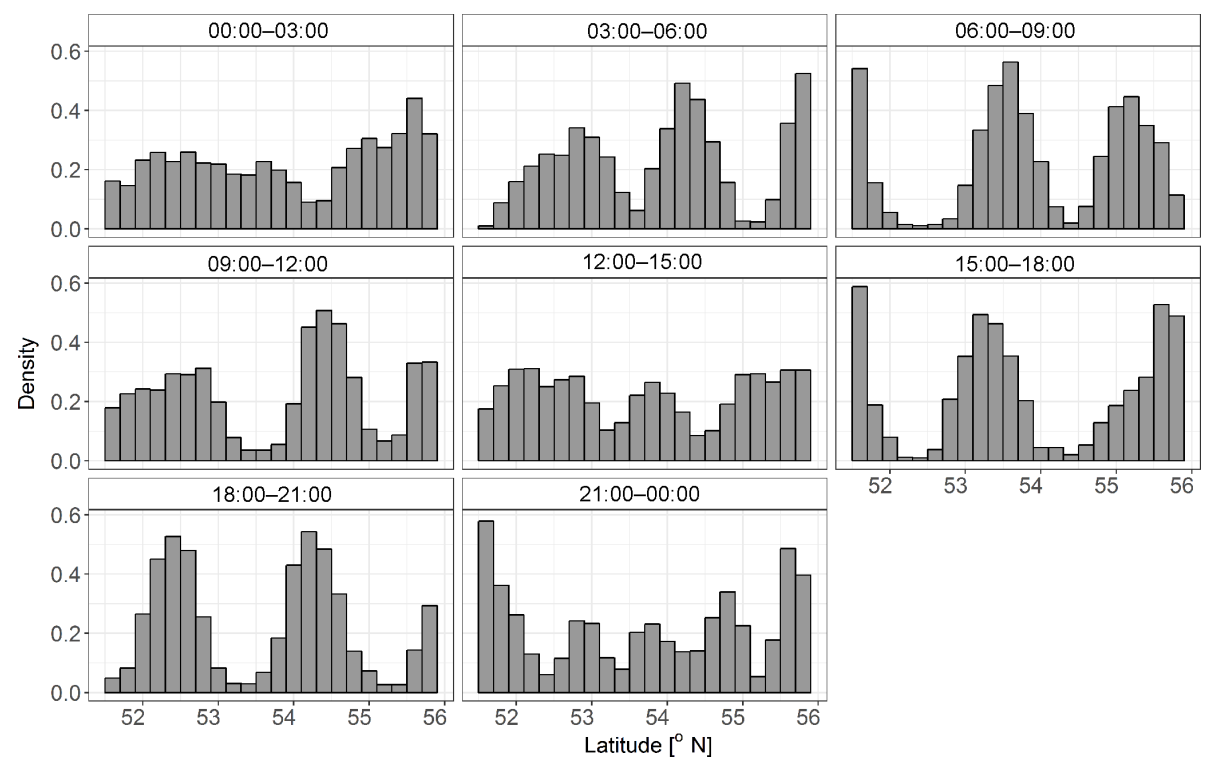

Figure 4. Temporal coverage of the latitudinal range $\left(0.2^{\circ}\right.$ bins $)$ spanned by the ferry route expressed as a count density (frequency of occurrence normalised by the total number of observations in each latitude bin) for all data points which satisfied the data screening criteria (Sect. 2.2.1) during the measurement period 1 January 2015-31 December 2017.

Table 1. List of instruments and observables recorded on board the Rosyth (Scotland, UK; $56^{\circ} 1^{\prime} 21.611^{\prime \prime} \mathrm{N}, 3^{\circ} 26^{\prime} 21.558^{\prime \prime} \mathrm{W}$ ) to Zeebrugge (Belgium; $51^{\circ} 21^{\prime} 16.96^{\prime \prime} \mathrm{N}, 3^{\circ} 10^{\prime} 34.645^{\prime \prime} \mathrm{E}$ ) freight ferry.

\begin{tabular}{|c|c|c|}
\hline Observable & Unit & Instrument \\
\hline $\mathrm{CO}_{2}$ dry mole fraction & $\mathrm{ppm}$ & Picarro 1301 CRDS \\
\hline $\mathrm{CH}_{4}$ dry mole fraction & $\mathrm{ppb}$ & Picarro 1301 CRDS \\
\hline $\begin{array}{l}\text { Apparent wind speed } \\
\text { (with respect to moving ship) }\end{array}$ & $\mathrm{m} \mathrm{s}^{-1}$ & Vaisala WXT520 \\
\hline $\begin{array}{l}\text { Apparent wind direction } \\
\text { (wind blowing from with respect } \\
\text { to prow of moving ship) }\end{array}$ & $\circ$ & Vaisala WXT520 \\
\hline Air temperature & ${ }^{\circ} \mathrm{C}$ & Vaisala WXT520 \\
\hline Ambient pressure & $\mathrm{hPa}$ & Vaisala WXT520 \\
\hline Relative humidity & $\%$ & Vaisala WXT520 \\
\hline Ship speed & $\mathrm{kt}$ & Garmin $18 \times$ series GPS \\
\hline Ship bearing & degrees & Garmin $18 \times$ series GPS \\
\hline Ship position, latitude & decimal & Garmin $18 \times$ series GPS \\
\hline Ship position, longitude & decimal & Garmin $18 \times$ series GPS \\
\hline
\end{tabular}

every month at Mace Head for the long-term target gas were $0.01 \pm 0.02 \mathrm{ppm}$ for $\mathrm{CO}_{2}$ (both analysers) and $0.08 \pm 0.19$ and $0.01 \pm 0.17 \mathrm{ppb}$ for $\mathrm{CH}_{4}$ with analyser G1301 and G2301, respectively. The measurements are processed every day at LSCE (Hazan et al., 2016), ensuring a high level of quality control of the dataset. The maintenance of the analysers is coordinated through close collaboration between LSCE, EPA, and the National University of Ireland, Galway (NUIG).

\subsection{Mass balance budgets}

The main underlying assumptions of the mass balance approach used to calculate the spatially integrated emissions budgets of $\mathrm{CO}_{2}$ and $\mathrm{CH}_{4}$ from the Republic of Ireland, Northern Ireland, Wales, and England are five-fold.

- Under westerly wind conditions, the Mace Head station on the west coast of Ireland $\left(53^{\circ} 20^{\prime} \mathrm{N}, 9^{\circ} 54^{\prime} \mathrm{W}\right.$; $5 \mathrm{~m}$ a.s.1., tower height $23 \mathrm{~m}$ ) receives relatively clean Atlantic air, whilst the concentrations measured along the ferry route result from enhancement in $\mathrm{CH}_{4}$ and $\mathrm{CO}_{2}$ due to land sources over the travel path of the air mass. The concentrations at Mace Head are representative of the inflow into the British Isles in both space and time.

For each nominal temporal averaging period we assume the following.

- The planetary boundary layer (PBL) height is constant over the entire spatial domain bounded to the east and west by the ferry route and the meridian at the Mace Head station location. The north and south boundaries of the domain are taken as the extrema of the latitudinal range covered by the ferry route.

- The air columns between the land surface and the top of the PBL are well-mixed.

- The horizontal wind direction is uniform.

- There is no mass leakage out of or ingress into the 3-D domain.

In the analysis, conditions are selected to fulfil these assumptions as best as possible. Data screening and quality control are discussed in Sect. 2.2.1, the procedure for estimating background concentrations (baselines) and PBL heights 
Table 2. Details of the weekly auto-calibration sequence (interval $169 \mathrm{~h}$ ) and reference gases. The reference gases were calibrated by the Swiss Federal Laboratories for Materials Testing and Research (World Calibration Centre WCC-EMPA, Dübendorf, Switzerland) using a Picarro 1301 CRDS. Calibration scales (NOAA/ ESRL): WMO-CH 4 -X2004 for methane and WMO-CO 2 -X2007 for carbon dioxide. The measurement uncertainties correspond to the standard deviation multiplied by a coverage factor $k=2$, which provides a level of confidence of approximately $95 \%$.

\begin{tabular}{llrlll}
\hline Step & Type & $\begin{array}{r}\text { Time } \\
\text { interval (s) }\end{array}$ & $\begin{array}{l}\text { Calibration } \\
\text { standard number }\end{array}$ & $\begin{array}{l}\mathrm{CO}_{2} \pm \text { uncertainty } \\
(\mathrm{ppm})\end{array}$ & $\begin{array}{l}\mathrm{CH}_{4} \pm \text { uncertainty } \\
(\mathrm{ppb})\end{array}$ \\
\hline 1 & Purge & 300 & 1 & $384.23 \pm 0.15$ & $1815.36 \pm 1.45$ \\
2 & Measurement & 900 & 1 & $384.23 \pm 0.15$ & $1815.36 \pm 1.45$ \\
3 & Purge & 300 & 2 & $418.29 \pm 0.16$ & $2018.06 \pm 1.58$ \\
4 & Measurement & 900 & 2 & $418.29 \pm 0.16$ & $2018.06 \pm 1.58$ \\
5 & Purge & 300 & 3 & $474.86 \pm 0.18$ & $2426.77 \pm 1.86$ \\
6 & Measurement & 900 & 3 & $474.86 \pm 0.18$ & $2426.77 \pm 1.86$ \\
7 & Purge & 300 & Ambient air & Ambient air & Ambient air \\
\hline
\end{tabular}

are presented in Sect. 2.2.2 and 2.2.3, and, finally, the mass balance budget and uncertainty calculations are discussed in Sect. 2.2.4 and 2.2.5.

\subsubsection{Data screening}

Prior to time averaging and flux calculation, raw data points were excluded from further processing if any of the following criteria were realised.

- The ship was in port.

- A calibration took place.

- $72 \mathrm{~h}$ back trajectories (500 m a.g.l.) for the Mace Head site and one point along the route of the ferry $\left(54.548^{\circ} \mathrm{N}, 0.233^{\circ} \mathrm{W}\right)$ as calculated with HYSPLIT (NOAA Air Resources Laboratory, 2018) exhibited airflow patterns inconsistent with the mass balance assumptions (i.e. non-westerly flow, evidence of recirculation).

- The relative wind direction measured on the ship (the fixed reference point being the prow of the vessel) was outside the range $150-210^{\circ}$. This criterion was used to exclude data points potentially contaminated by onboard activities (e.g. emissions from chimney stacks).

- The wind direction measured on the ship (absolute direction from the north, corrected for the movement of the ship) was outside the westerly range $\left(240-300^{\circ}\right)$.

- The wind direction measured at the Mace Head station (data source: Met Éireann, 2018) was outside the westerly range $\left(240-300^{\circ}\right)$.

The temporal coverage of the data points which satisfied the criteria listed above is presented in histogram form in Fig. 4. The full details of the data availability for the study period 2015-2017 are summarised in Table S1 of the Supplement.

\subsubsection{Concentration baselines}

The time series of hourly concentrations of $\mathrm{CO}_{2}$ and $\mathrm{CH}_{4}$ measured at Mace Head and filtered for westerly flow (wind direction range $240-300^{\circ}$ ) were used to construct continuous baselines for the measurement period February 2014 December 2017 (Fig. 5). The time series of both gases exhibited well-defined seasonal cycles characterised by high concentrations towards the end of the winter and lower concentrations in summer. The baselines were constructed for the data period 1 January 2014-31 December 2017 by applying regressions by parts consisting of linear and non-linear (Gaussian) fitting functions over the temporal domain. The composite fitting functions provided smoothing and gap filling of the measured mole fraction time series and were subsequently used to construct continuous time series of background concentrations of $\mathrm{CO}_{2}$ and $\mathrm{CH}_{4}$ with a 5 min time step, which corresponded to the averaging interval used for the data measured on the ferry.

\subsubsection{Estimation of the planetary boundary layer height}

The Weather Research and Forecast model version $\quad 3.7 .1 \quad$ (https://www.mmm.ucar.edu/ weather-research-and-forecasting-model, last access: 5 March 2019) (Skamarock et al., 2008) was used for this work. The WRF model initial and boundary conditions were derived from the US National Center for Environmental Prediction (NCEP)/National Center for Atmospheric Research (NCAR) Global Forecast System (GFS) at $1.0^{\circ} \times 1.0^{\circ}$ resolution (National Centers for Environmental Prediction, 2000), including Newtonian nudging every $6 \mathrm{~h}$. The Yonsei University (YSU) scheme for planetary boundary layer physics was used here (Hong et al., 2006).

The WRF model set-up used in this study had three nested domains with a horizontal resolution of $0.5^{\circ} \times 0.5^{\circ}$ for the European domain, $0.16^{\circ} \times 0.16^{\circ}$ for the British Isles domain, 

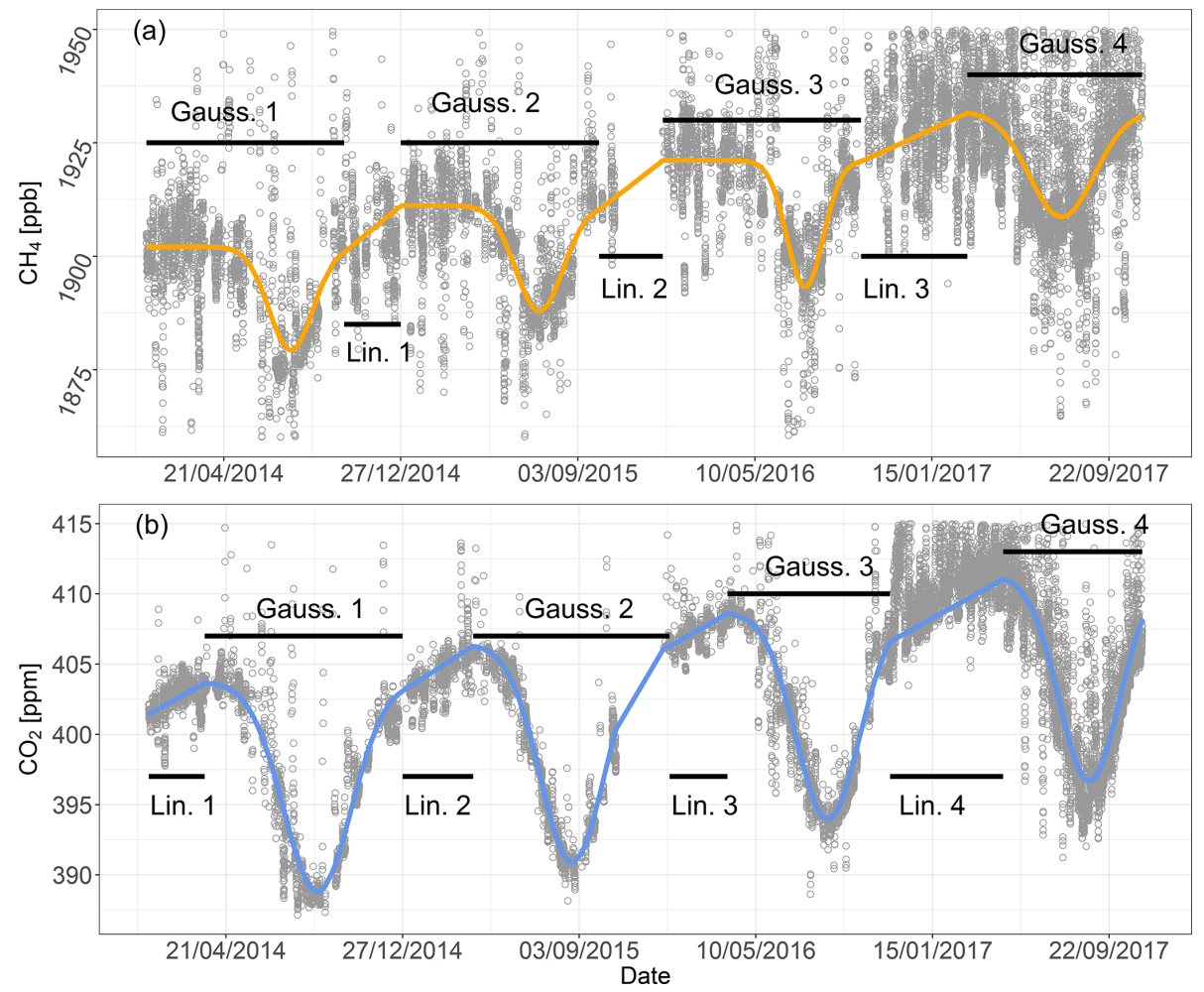

Figure 5. Hourly time series filtered for westerly wind directions (range 150-210 $)$ measured at the Mace Head station (open circles) of (a) $\mathrm{CH}_{4}$ and (b) $\mathrm{CO}_{2}$ mole fractions. Smoothing and gap filling of the original time series was achieved by applying linear (Lin.) and non-linear (Gauss.) regressions by parts for the data period 1 January 2014-31 December 2017 (solid lines).

and $0.055^{\circ} \times 0.055^{\circ}$ for the UK model domain. The vertical column was divided into 21 layers from the surface (bottom layer $\sim 50 \mathrm{~m})$ up to $100 \mathrm{hPa}(\sim 16 \mathrm{~km})$ in sigma coordinates.

The WRF model hourly output from the UK domain was used to calculate spatial means and standard deviations of wind speed, wind direction, and planetary boundary layer height. We estimate the spatial averages at a height of $\sim$ $450 \mathrm{~m}$ (fourth model layer) for an area defined as follows: lower left corner coordinates of 52.0 latitude and -10.0 longitude and upper right corner of 57.0 latitude and 3.0 longitude. Time series of hourly averages of wind speed, wind direction, and PBL height were constructed for the data period 1 January 2014 to 31 December 2017. These hourly values were extrapolated to the $5 \mathrm{~min}$ concentrations and ancillary (e.g. meteorological, ship speed, coordinates) time series by assigning PBL height and wind speed to the corresponding hour in the $5 \mathrm{~min}$ dataset (e.g. the mean PBL height value estimated for the time period 03:00-04:00 UTC on 13 June 2015 was assigned to all $5 \mathrm{~min}$ averaging intervals from 03:00 to 03:55 UTC).

Daily means and standard deviations obtained by averaging the hourly values of the PBL heights derived from WRF for the study period 2015-2017 are presented in Fig. S1 of the Supplement.

\subsubsection{Mass balance calculations}

The flux $F_{C}$ of species $C$ through a two-dimensional, vertical plane perpendicular to the mean wind direction can be expressed as (Cambaliza et al., 2014; White et al., 1976)

$F_{C}=\int_{z_{\min }}^{z_{\max }} \int_{x_{\min }}^{x_{\max }}\left(C-C_{b}\right) \cdot U \perp^{U} \mathrm{~d} x \mathrm{~d} z$.

$C$ and $C_{b}$ are the number of moles of species $c$ downwind and upwind of the vertical plane, and $U_{\perp}$ is the mean wind speed perpendicular to the plane bounded horizontally by $x_{\min }$ and $x_{\max }$ and vertically by $z_{\min }$ and $z_{\max }$.

$F_{c}$ can be expressed explicitly in units of $\mathrm{mol} \mathrm{s}^{-1}$ as

$F_{C}=\int_{z_{\text {ground }}}^{z_{\text {PBL }}} \int_{x_{\min }}^{x_{\max }} \Delta \chi_{C} \cdot U \cdot n_{\text {air }}(z) \cos \theta \mathrm{d} x \mathrm{~d} z$.

Here, $\Delta \chi_{c}$ is the enhancement of compound $c$ in mol mol ${ }^{-1}$ above background, $n_{\text {air }}(z)$ is the air density at height $z$, $\cos \theta \mathrm{d} x$ (Fig. 6) is the ship track increment projected onto the crosswind plane, and $U$ is the mean wind speed within the PBL obtained by the WRF model described in Sect. 2.2.3. Figure 6 illustrates the mass balance calculation procedure. 
In practice, despite the 3 years of data, no single journey satisfied all the quality control criteria detailed in Sect. 2.2.1 perfectly for all of the individual $5 \mathrm{~min}$ averaging intervals, and we opted to aggregate the good $5 \mathrm{~min}$ data points into $0.2^{\circ}$ wide latitude bins using seasonal grouping for each data year. The baseline mole fractions used to calculate the upwind enhancement of compound $c$ were time-shifted in order to account for the mean air mass travel time across the domain (time taken to travel west-east from the longitude of the Mace Head station to the location of the ferry at hourly mean wind speed derived from the WRF model; see Table S2 for seasonal mean values and standard deviations).

Seasonal budgets were then calculated from the aggregated data as

$$
\begin{aligned}
& F_{C}=\underbrace{\sum_{i=1}^{\text {lat bins }} \underbrace{\Delta \chi(i)}_{\equiv \mathrm{I}}}_{\equiv \mathrm{II}} \\
& \cdot \underbrace{\underbrace{\prime}}_{\chi_{C}(\Delta t) \cdot U(\Delta t) \cdot \cos (\theta(\Delta t)) \cdot \int_{z_{\text {ground }}}^{z \mathrm{PBL}} n_{\text {air }}(\Delta t, z) \mathrm{d} z} .
\end{aligned}
$$

In Eq. (3), term I is the distance travelled per nominal latitude bin $i$ along a meridian (the crosswind projection is done by multiplication with $\cos (\theta)$ in term II) and term II is the mean (the horizontal bar denotes averaging), for latitude bin $i$, of the product over all the $5 \mathrm{~min}$ averaging periods $(\Delta t)$ that passed the quality control tests.

The total variability in seasonal fluxes was approximated as

$$
\Delta F_{c}=\frac{\sqrt{\sum_{i=1}^{\text {lat bins }} \Delta x(i) \cdot \sigma^{2}\left(\Delta \chi_{C}(\Delta t) \cdot U(\Delta t) \cdot \cos \theta(\Delta t)\right.}}{\left.\int_{z_{\text {ground }}}^{\text {PBL }} n_{\text {air }}(\Delta t, z) \mathrm{d} z\right)},
$$

where $\sigma$ denotes the standard deviation of the mean. Finally, the annual budgets were obtained by summing the seasonal budgets.

\subsubsection{Uncertainty and error propagation}

In addition to the temporal variability $\Delta F_{c}$, (Eq. 4) we calculated the uncertainty on the total fluxes arising from the uncertainties on the individual terms of the mass balance equation. Noting that $\mathrm{d} x$ represents the distance travelled by the ship with speed $v_{\text {ship }}$ during the infinitesimal time interval $\mathrm{d} t$, Eq. (2) can be reformulated to express the partial flux $f_{c}$ through a 2-D plane spanning the horizontal distance $\mathrm{d} x$ as a function of $v_{\text {ship }}$ and $\mathrm{d} t$ (Eq. 5).

$$
f_{C}=\int_{z_{\text {ground }}}^{z_{\text {PBL }}} \Delta \chi_{C} \cdot U \cdot n_{\text {air }}(z) \cdot \cos \theta \cdot v_{\text {ship }} \mathrm{d} t \mathrm{~d} z
$$

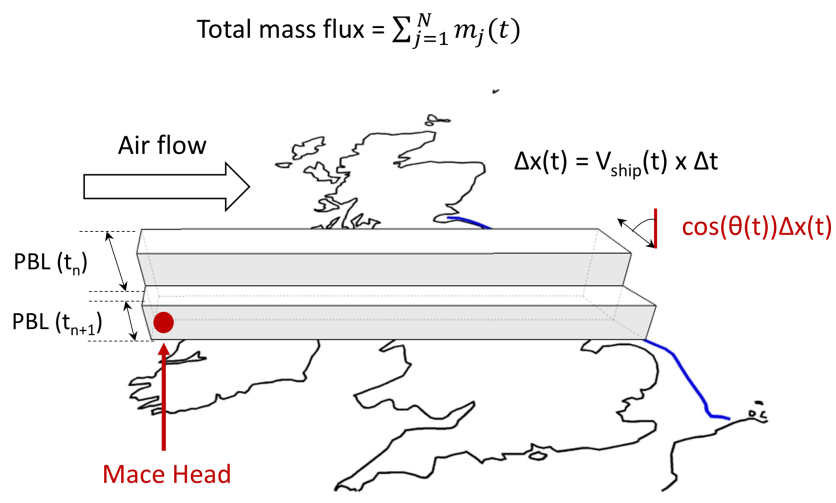

Figure 6. Schematic of the mass balance flux calculation procedure expressed in Eq. (2). The total flux is the sum of flux elements through a vertical surface with the height of the planetary boundary layer (PBL) and the width the ship track increment $\left(\Delta x=v_{\text {ship }}(\mathrm{t})\right.$ $\Delta t$ ) during a nominal averaging time interval $\Delta t$ projected onto the crosswind direction $(\cos (\theta(t)) \Delta x)$.

Applying the rules of error propagation, the error on the flux term $f_{c}\left(\delta f_{c}\right)$ is given by (with $N_{\text {air }}$, the value of the integral of $n_{\text {air }}(z)$ evaluated over time step $\left.\mathrm{d} t\right)$

$$
\begin{aligned}
\frac{\delta f_{c}}{\left|f_{c}\right|} & =\sqrt{\left(\frac{\delta \chi_{c}}{\chi_{c}}\right)^{2}+\left(\frac{\delta U}{U}\right)^{2}+\left(\frac{\delta \cos \theta}{\cos \theta}\right)^{2}+\left(\frac{\delta v_{\text {ship }}}{v_{\text {ship }}}\right)^{2}} \\
& +\left(\frac{\delta \mathrm{d} t}{\mathrm{~d} t}\right)^{2}+\left(\frac{\delta \int_{z_{\text {ground }}}^{z \text { PBL }} n_{\text {air }}(z) \mathrm{d} z}{N_{\text {air }}}\right)^{2}
\end{aligned}
$$

Assuming that (a) the uncertainty on $\mathrm{d} t$ is negligible and (b) the uncertainty on the PBL height ( $z_{\mathrm{PBL}}$ ) is the dominant error term in the integral of $n_{\text {air }}(z)$ between height $z_{\text {ground }}$ and $z_{\mathrm{PBL}}$, Eq. (6) can be approximated as

$$
\begin{aligned}
& \frac{\delta f_{c}}{\left|f_{c}\right|} \approx \sqrt{\left(\frac{\delta \chi_{c}}{\chi_{c}}\right)^{2}+\left(\frac{\delta U}{U}\right)^{2}+\left(\frac{\delta \cos \theta}{\cos \theta}\right)^{2}+\left(\frac{\delta v_{\text {ship }}}{v_{\text {ship }}}\right)^{2}} \\
&+\left[\frac{\left(n_{\text {air }}\left(z_{\mathrm{PBL}}\right)-n_{\text {air }}\left(z_{\text {ground }}\right)\right) \cdot \delta z_{\mathrm{PBL}}}{N_{\text {air }}}\right]^{2}
\end{aligned}
$$

Finally, similarly to Eq. (4), the total error on the flux $F_{c}$ $\left(\delta F_{c}\right)$ calculated for a complete transect of the ship between $x_{\min }$ and $x_{\max }$ is given by

$$
\frac{\delta F_{c}}{\left|F_{c}\right|}=\sqrt{\sum_{i}^{N}\left\{\left(\frac{\delta f_{c}}{\left|f_{c}\right|}\right)_{i}\right\}^{2}} .
$$

The standard deviations of the individual terms in Eq. (7), calculated for each $5 \mathrm{~min}$ averaging period and averaged over each nominal latitude bin, were used as proxies for uncertainties. Table S2 summarises the total uncertainty on the calculated emissions budgets and the relative contributions of the individual terms in Eq. (7). 
Table 3. Seasonal and annual budgets for $\mathrm{CO}_{2}$ and $\mathrm{CH}_{4}$ for the United Kingdom (excluding Scotland) and Ireland estimated by a mass balance approach using concentrations measured at the Mace Head station (Republic of Ireland; 53 $19^{\prime} 19.2^{\prime \prime} \mathrm{N}, 9^{\circ} 54^{\prime} 3.599^{\prime \prime} \mathrm{W}$ ) and on board the freight ferry which served the Rosyth (Scotland, UK; $56^{\circ} 1^{\prime} 21.611^{\prime \prime} \mathrm{N}, 3^{\circ} 26^{\prime} 21.558^{\prime \prime} \mathrm{W}$ ) to Zeebrugge (Belgium; $51^{\circ} 21^{\prime} 16.96^{\prime \prime} \mathrm{N}$, $\left.3^{\circ} 10^{\prime} 34.645^{\prime \prime} \mathrm{E}\right)$ route. Seasonal budgets were calculated by year when sufficient data were available; seasonal budgets were also derived using the entire dataset with and without segregation of the raw fluxes into day and night components. Annual budgets were calculated with and without seasonality and with and without day-night segregation. The variability and uncertainty terms were calculated using Eq. (4) and Eqs. (7)-(8), respectively.

\begin{tabular}{|c|c|c|c|}
\hline \multirow[b]{2}{*}{ Season } & \multirow[b]{2}{*}{ Year } & \multicolumn{2}{|c|}{ Flux \pm uncertainty (variability) $[\mathrm{Tg}]$} \\
\hline & & $\mathrm{CO}_{2}$ & $\mathrm{CH}_{4}$ \\
\hline Winter & 2015 & - & - \\
\hline Spring & 2015 & $92.6 \pm 21.1(34.7)$ & $0.43 \pm 0.13(0.11)$ \\
\hline Summer & 2015 & $27.6 \pm 79.5(46.8)$ & $0.45 \pm 0.72(0.09)$ \\
\hline Autumn & 2015 & $286.4 \pm 35.4(47.6)$ & $0.61 \pm 0.07(0.14)$ \\
\hline Winter & 2016 & - & - \\
\hline Spring & 2016 & - & - \\
\hline Summer & 2016 & $131.6 \pm 82.6(36.5)$ & $0.39 \pm 0.25(0.09)$ \\
\hline Autumn & 2016 & $261.3 \pm 164.3(56.4)$ & $0.75 \pm 0.40(0.16)$ \\
\hline Winter & 2017 & $341 \pm 17.2(62.1)$ & $0.78 \pm 0.05(0.38)$ \\
\hline Spring & 2017 & $197.5 \pm 40.4(27.9)$ & $0.49 \pm 0.14(0.07)$ \\
\hline Summer & 2017 & $155 \pm 81.8(77.6)$ & $0.32 \pm 0.14(0.06)$ \\
\hline Autumn & 2017 & $363.4 \pm 12.1(65.7)$ & $1.03 \pm 0.04(0.15)$ \\
\hline Winter & $2016 \& 2017$ & $379.1 \pm 26.6(68.8)$ & $0.89 \pm 0.08(0.35)$ \\
\hline Spring & 2015-2017 & $161.5 \pm 30.9(41.2)$ & $0.55 \pm 0.08(0.17)$ \\
\hline Summer & $2015-2017$ & $123.6 \pm 76.9(64.6)$ & $0.38 \pm 0.25(0.09)$ \\
\hline Autumn & $2015-2017$ & $250.2 \pm 200.1(57.8)$ & $0.72 \pm 0.40(0.16)$ \\
\hline Winter (day-night weighting) & $2016 \& 2017$ & $357.8 \pm 26.2(66.8)$ & $0.82 \pm 0.08(0.34)$ \\
\hline Spring (day-night weighting) & $2015-2017$ & $162.5 \pm 30.9(55.0)$ & $0.57 \pm 0.08(0.22)$ \\
\hline Summer (day-night weighting) & 2015-2017 & $127.7 \pm 76.9(78.7)$ & $0.39 \pm 0.25(0.12)$ \\
\hline Autumn (day-night weighting) & $2015-2017$ & $232.9 \pm 57.8(72.2)$ & $0.67 \pm 0.16(0.19)$ \\
\hline Annual (from seasonal budgets) & $2015-2017$ & $914.4 \pm 218.1(118.1)$ & $2.55 \pm 0.48(0.43)$ \\
\hline Annual (from seasonal, day-night weighted budgets) & $2015-2017$ & $881.0 \pm 125.8(137.5)$ & $2.44 \pm 0.30(0.47)$ \\
\hline Annual (no seasons) & $2015-2017$ & $708.3 \pm 270.4(241.9)$ & $2.1 \pm 0.67(0.63)$ \\
\hline Annual (no seasons, day-night weighted) & $2015-2017$ & $598.3 \pm 250.1(274.9)$ & $1.66 \pm 0.60(0.94)$ \\
\hline UK (BEIS, 2017) & 2015 & 415.1 & 2.1 \\
\hline RoI (EPA, 2017) & 2015 & 38.4 & 0.53 \\
\hline Scotland (Inventory, 2018) & 2015 & 30.8 & 0.34 \\
\hline Total inventory (UK-Scotland + RoI) & 2015 & 422.7 & 2.29 \\
\hline Ganesan (Ganesan et al., 2015) & 2012-2014 & - & $1.65-2.67$ \\
\hline Bergamaschi (Bergamaschi et al., 2015) & 2006-2007 & & $3.1-3.5$ \\
\hline
\end{tabular}

\section{Results}

\subsection{Seasonal and annual fluxes}

The fluxes of $\mathrm{CH}_{4}$ (Fig. 7) and $\mathrm{CO}_{2}$ (Fig. 8) calculated from measurements on board the North Sea ferry were variable in space (over the latitude range $51.35-56.15^{\circ} \mathrm{N}$ ) and time. The calculated emissions of $\mathrm{CO}_{2}$ and $\mathrm{CH}_{4}$ had maxima in winter (DJF; 379.1 $\pm 26.2 \mathrm{Tg} \mathrm{CO}_{2}, 0.89 \pm 0.08 \mathrm{Tg} \mathrm{CH}_{4} ; 2016$ and 2017 winter data only). Emission minima were observed in summer (JJA; $123.6 \pm 76.9 \mathrm{Tg} \mathrm{CO}_{2} ; 0.38 \pm 0.25 \mathrm{Tg} \mathrm{CH}_{4}$; Table 3). Springtime (MAM) emissions were $161.5 \pm 30.9 \mathrm{Tg}$ for $\mathrm{CO}_{2}$ and $0.55 \pm 0.08 \mathrm{Tg}$ for $\mathrm{CH}_{4}$, and in autumn (SON) the measured emissions were $250.2 \pm 200.1 \mathrm{Tg}$ for $\mathrm{CO}_{2}$ and $0.72 \pm 0.40 \mathrm{Tg}$ for $\mathrm{CH}_{4}$. For $\mathrm{CO}_{2}$ and $\mathrm{CH}_{4}$, a statistically sig- nificant difference in seasonal budgets was found between winter and spring as well as between winter and summer. For both gases, the differences in emissions between spring and summer were not statistically significant, whilst for autumn the total uncertainty was large $\left(80 \%\right.$ uncertainty for $\mathrm{CO}_{2}$ and $56 \%$ for $\mathrm{CH}_{4}$ ). Annual budgets, estimated from seasonal values, were $914.4 \pm 218.1 \mathrm{Tg}$ for $\mathrm{CO}_{2}$ and $2.55 \pm 0.48$ for $\mathrm{CH}_{4}$. Without accounting for seasonality (i.e. using all data without seasonal segregation, which could weight towards the periods of the year for which the most data were available), the emissions budgets were $708.3 \pm 270.4 \mathrm{Tg}$ for $\mathrm{CO}_{2}$ and $2.1 \pm 0.67$ for $\mathrm{CH}_{4}$.

In winter, spring, and autumn, the largest fluxes of both gases were found in a broad central latitudinal band (52- 


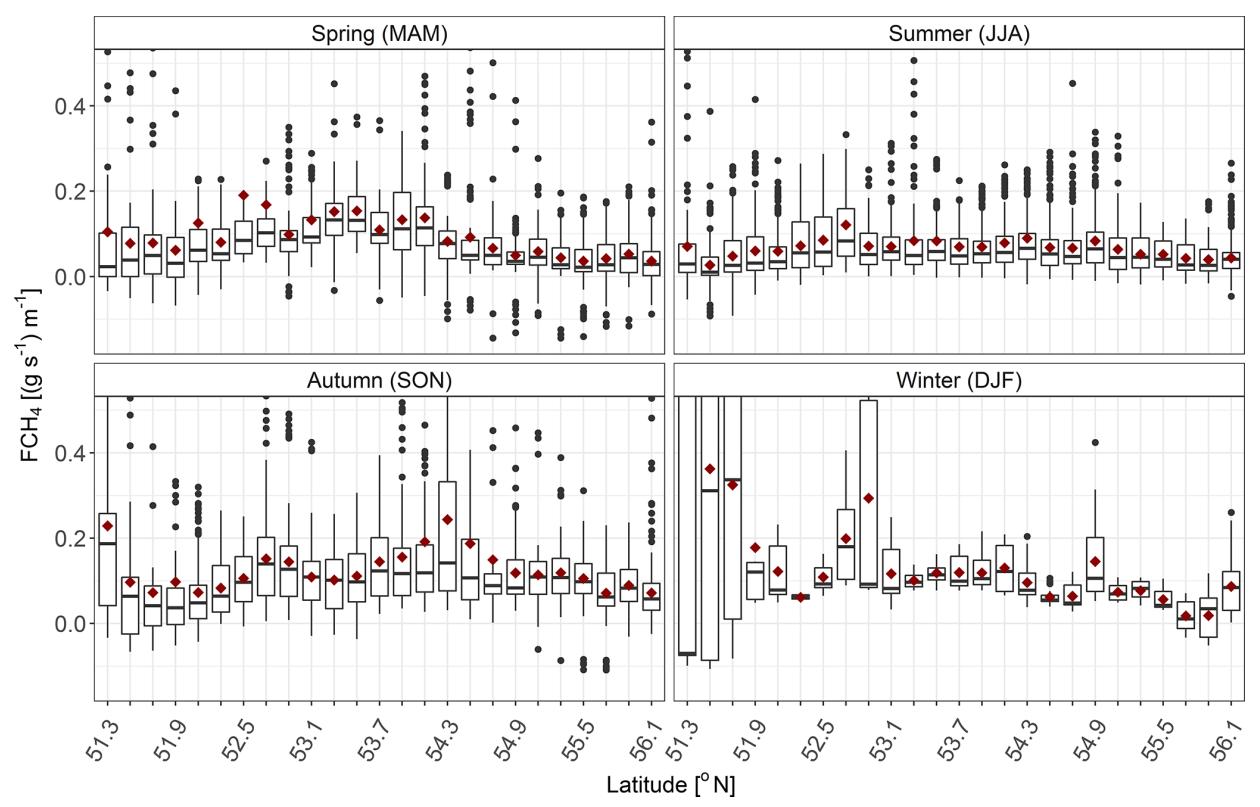

Figure 7. Box and whisker plots of 5 min binned averages of $\mathrm{CH}_{4}$ fluxes along the route of the ferry (latitude bin width: $0.2^{\circ}$ ). The horizontal bar within each box corresponds to the median for a given latitude bin, the upper and lower hinges represent the 75th and 25th quantiles, respectively, and the upper and lower whiskers indicate the largest-smallest observation less-greater than or equal to upper-lower hinge $\pm 1.5^{*}$ IQR (inter-quantile range), respectively. The outliers are represented by solid circles and arithmetic means by red diamonds. The flux is integrated over the height of the planetary boundary layer and expressed in units of mass flux per metre travelled crosswind within each latitude bin per unit time.

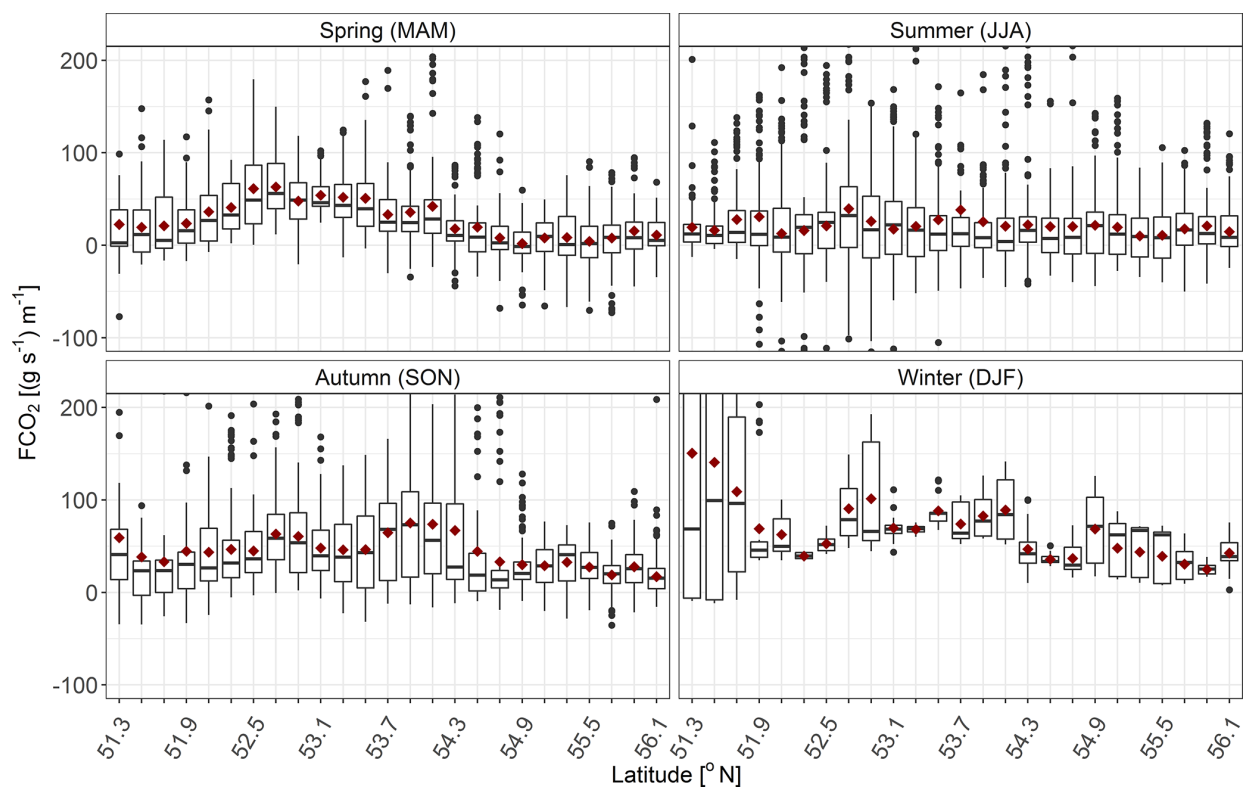

Figure 8. Box and whisker plots of 5 min binned averages of $\mathrm{CO}_{2}$ fluxes along the route of the ferry (latitude bin width: $0.2^{\circ}$ ). The horizontal bar within each box corresponds to the median for a given latitude bin, the upper and lower hinges represent the 75 th and 25 th quantiles, respectively, and the upper and lower whiskers indicate the largest-smallest observation less-greater than or equal to upper-lower hinge $\pm 1.5^{*} \mathrm{IQR}$ (inter-quantile range), respectively. The outliers are represented by solid circles and arithmetic means by red diamonds. The flux is integrated over the height of the planetary boundary layer and expressed in units of mass flux per metre travelled crosswind within each latitude bin per unit time. 


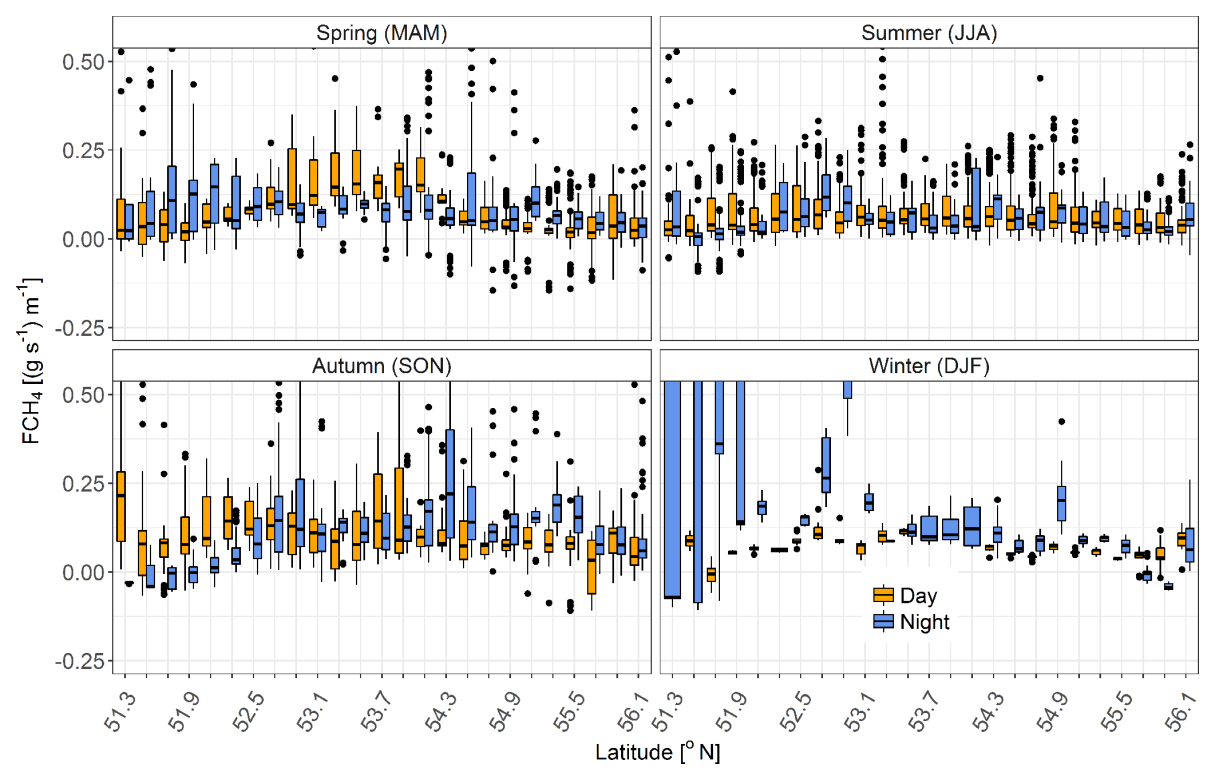

Figure 9. Box and whisker plots of $5 \mathrm{~min}$ binned averages of $\mathrm{CH}_{4}$ fluxes along the route of the ferry (latitude bin width: $0.2^{\circ}$ ) segregated into day and night contributions. The horizontal bar within each box corresponds to the median for a given latitude bin, the upper and lower hinges represent the 75th and 25th quantiles, respectively, and the upper and lower whiskers indicate the largest-smallest observation lessgreater than or equal to upper-lower hinge $\pm 1.5^{*} \mathrm{IQR}$ (inter-quantile range), respectively. The outliers are represented by solid circles and arithmetic means by red diamonds. The flux is integrated over the height of the planetary boundary layer and expressed in units of mass flux per metre travelled crosswind within each latitude bin per unit time.

$54^{\circ} \mathrm{N}$; Figs. 7 and 8). The lowest emissions were observed in summer across the entire spatial domain and they exhibited a smaller increment in the $52-54^{\circ} \mathrm{N}$ band compared to the fringes of the domain than in other seasons.

\subsection{Diurnal variability}

There were differences between day (defined arbitrarily as 09:00 to 18:00) and night fluxes, particularly in spring and summer (Figs. 9 and 10). Median daytime $\mathrm{CO}_{2}$ fluxes were negative for latitudes in the range 54.5 to $55.9^{\circ} \mathrm{N}$ in spring; in summer, negative $\mathrm{CO}_{2}$ fluxes were found at 54.5 and 55.3$55.5^{\circ} \mathrm{N}$. It is important to note that air mass transit time between the inflow and outflow points of the domain varied from a median of $11 \mathrm{~h}$ in winter to $19 \mathrm{~h}$ in summer, which means that the day and night periods did overlap.

Seasonal and annual budgets were recalculated using day and night fluxes weighted by day length (Table 3 ) in order to assess the impacts of uneven day-night data density distributions over the spatial domain caused by the relatively slow travel speed of the ship and the random data gaps introduced by changing wind direction and measurement downtime. The annual budgets calculated with day-night flux segregation were smaller than those obtained without day-night partitioning, but the differences were not statistically significant and, in general, separating fluxes into day and night components increased the uncertainties on the final budgets both at the seasonal and annual levels.
The annual budgets calculated using all available data were smaller than those obtained from seasonal budgets (both with and without day-night segregation); however, the only statistically significant difference was between the annual budget of $\mathrm{CO}_{2}$ obtained from seasonal data and the budget estimated with day-night weighting but without seasonality.

The annual budgets for both gases obtained without accounting for the seasonality in data coverage were consistent with inventory data but the measurement uncertainties were large $36 \%$ and $32 \%$ for $\mathrm{CH}_{4}$ with and without day-night weighting, with counterpart uncertainties on $\mathrm{CO}_{2}$ budgets of $42 \%$ and $38 \%$, respectively). The annual budgets of $\mathrm{CH}_{4} \mathrm{ob}-$ tained from seasonal budgets were in good agreement with inventory data, with uncertainties of $12 \%$ and $19 \%$ for estimates calculated with and without day-night weighting, respectively. In contrast, $\mathrm{CO}_{2}$ budgets were almost double the inventory value, with uncertainties of $14 \%$ and $24 \%$ for estimates calculated with and without day-night weighting.

The seasonal mass balance fluxes of $\mathrm{CH}_{4}$ and $\mathrm{CO}_{2}$ calculated from concentration measurements on the ferry were compared to known land sources and meteorological drivers of these gases. For both gases, there was a strong positive correlation between seasonal emissions measured on the ferry and the consumption of natural gas in the UK (Fig. 11). The correlation between GHG emissions and mean air temperature was negative and statistically significant (Fig. 12). 


\section{Discussion}

The mass balance approach presented here relies on simplifying assumptions to derive GHG budgets for a large part of the British Isles. The main assumptions are that (a) the air masses travel west to east, (b) the PBL height is constant over the spatial domain for each nominal averaging period, (c) there is no loss or input of mass into the domain other than from land sinks-sources, and (d) the air is well-mixed over the entire PBL height.

The data were filtered for westerly flow based on air mass back trajectories obtained from the HYSPLIT Trajectory Model (NOAA Air Resources Laboratory, 2018) daily $72 \mathrm{~h}$ runs at two coordinates: the Mace Head reference site and one ferry position halfway along its route. The back trajectories were run daily, commencing at midnight, and the air mass histories were assumed to be valid for an entire $24 \mathrm{~h}$ period and for the entire spatial domain. Of the four main assumptions listed above, points (c) and (d) are the most subjective because they could not be verified nor quantified. Assumption (a) (air mass travel from west to east) can be considered to be reasonably well-constrained owing to the data screening procedure at the preprocessing stage. Violations of the stationarity assumption (point b) due to significant changes in the mean PBL height at a sub-hourly time step would either be captured, in part or entirely, during the next hourly averaging period or go unnoticed in the case of very transient non-stationary events. Whilst the temporal variability of the mean PBL height for the spatial domain considered can be quantified and propagated through the emissions budget calculations as measurement uncertainty, the potential bias between model output and observations is unknown. Recent studies have compared different WRF parametrisation schemes with observed PBL height and found that, in general, the YSU scheme used in this study performs reasonably well in terms of predicting PBL height with minimum bias typically observed before midday (Hu et al., 2010; Banks et al., 2016; Tyagi et al., 2018; Xu et al., 2018); however, these studies also highlighted the fact that model performance can vary significantly between sites and time of day and that YSU tends to underestimate the PBL height over the sea (Tyagi et al., 2018). Comparisons between observations and model outputs of wind speed profiles for different parametrisation schemes also found substantial variability, both intra- and inter-model, with the YSU scheme exhibiting a tendency to overestimate wind speeds (Balzarini et al., 2014; Tyagi et al., 2018). The formation of sea breezes adds another level of complexity to the modelling of PBL height and wind speed, in particular in the southern North Sea where the orientation of the coastlines and their proximity to one another have been shown to induce sea breeze formation and to influence sea breeze type and offshore extent (Steele et al., 2013, 2015). Furthermore, not all WRF parametrisation schemes are equal in performance with respect to sea breeze conditions; recent studies show that the YSU scheme used here exhibited the smallest bias for wind speeds measured onshore under complex sea breeze conditions (Steele et al., 2015) and that it also captured the temporal evolution of the atmospheric boundary layer height better than other schemes (Salvador et al., 2016).

Intrinsic, unquantifiable biases on the mixing layer heights and mean wind speeds derived from the WRF model are hence likely. Wind speed and enhancement above background concentration were found to be to dominant uncertainty terms, jointly accounting for over $80 \%$ of the total uncertainty in all seasons (Table S2). In contrast, nudging the baseline concentrations measured at Mace Head by a time lag estimated from the mean air mass travel time had only a very modest impact on the final budgets (Table S2). The two measures of errors proposed in this paper (based on temporal variability and total uncertainty through error propagation) yield on the whole comparable results, with the main discrepancy found for the autumn budget (years used: 20152017) in which the total uncertainty was almost four-fold the value obtained by considering the temporal variability alone. The autumn uncertainty was brought in line with the temporal variability estimate for both gases when the day-night weighting was applied. Whilst the variability and the total uncertainty are useful as first approximations for the confidence in the emission budgets, they should be treated as potential lower limits because of the unquantified bias between WRF model outputs and actual values of the PBL height and wind speed.

The fluxes calculated under this data filtering regime were assumed to be representative of surface emissions and uptake over the land masses bounded by the spatial domain, and local influences (due to e.g. localised air recirculation) were assumed to be negligible. This assumption could not be tested on a point-per-point basis but the latitudinal trends for both $\mathrm{CH}_{4}$ and $\mathrm{CO}_{2}$ at the seasonal timescale (Figs. 7 and 8) are consistent with the demographics and the known spatial distributions of sources of GHGs over the latitudinal range considered. In particular, the emission peaks for $\mathrm{CO}_{2}$ observed around 52.5 and $54^{\circ} \mathrm{N}$ coincide with major urban centres in the British Midlands, namely Birmingham and Manchester, Liverpool, Leeds, and Sheffield, as well as Dublin further upwind in the Republic of Ireland. These conurbations are reported to be significant sources of $\mathrm{CO}_{2}$ by the UK's official National Atmospheric Emissions Inventory (NAEI, 2018a). The calculated $\mathrm{CH}_{4}$ emissions were elevated in the 52.5$54^{\circ} \mathrm{N}$ latitude band compared to the fringes of the domain. This agrees with the NAEI UK $\mathrm{CH}_{4}$ map (NAEI, 2018a), which shows large emissions from the western parts of England in that latitude band. The NAEI reports substantial $\mathrm{CH}_{4}$ emissions from the Cornwall area (SW England; latitudes $<51.3^{\circ} \mathrm{N}$ ), which might not always have registered in their entirety by the measurement system on the ferry because the port of Zeebrugge - the starting and end point of the vessel's route - lies at $51.21^{\circ} \mathrm{N}$. 


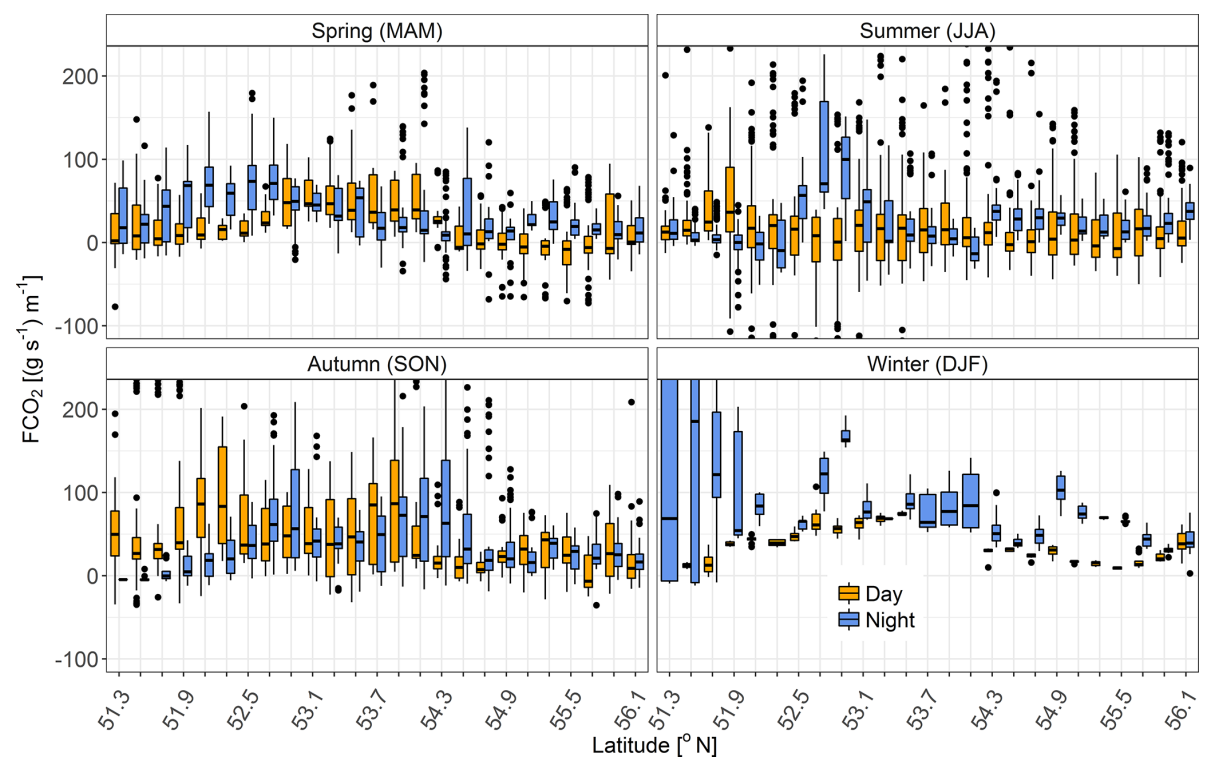

Figure 10. Box and whisker plots of $5 \mathrm{~min}$ binned averages of $\mathrm{CO}_{2}$ fluxes along the route of the ferry (latitude bin width: $0.2^{\circ}$ ) segregated into day and night contributions. The horizontal bar within each box corresponds to the median for a given latitude bin, the upper and lower hinges represent the 75th and 25th quantiles, respectively, and the upper and lower whiskers indicate the largest-smallest observation lessgreater than or equal to upper-lower hinge $\pm 1.5^{*} \mathrm{IQR}$ (inter-quantile range), respectively. The outliers are represented by solid circles and arithmetic means by red diamonds. The flux is integrated over the height of the planetary boundary layer and expressed in units of mass flux per metre travelled crosswind within each latitude bin per unit time.
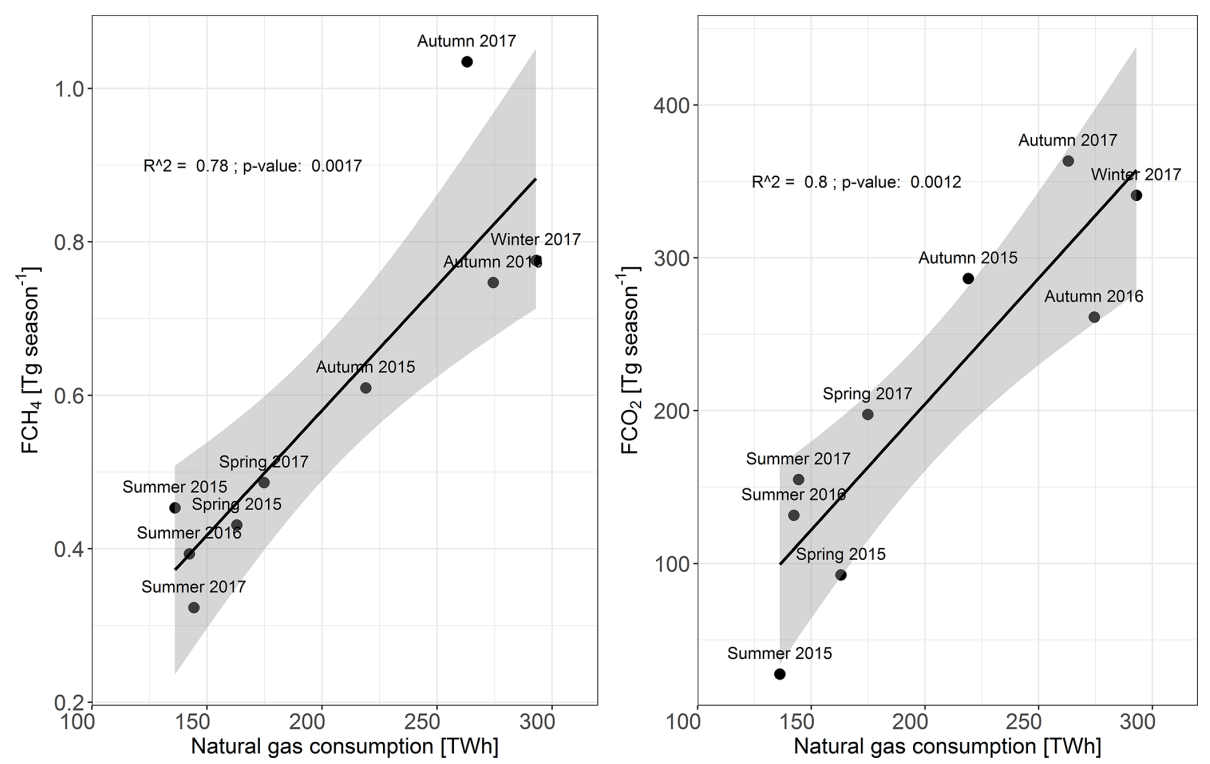

Figure 11. Seasonal budgets of $\mathrm{CH}_{4}$ and $\mathrm{CO}_{2}$ as a function of UK natural gas consumption (source: BEIS, 2018). The shaded area represents the $95 \%$ confidence interval of the linear regression.

The negative daytime fluxes of $\mathrm{CO}_{2}$ registered in summer for latitudes $>54.5^{\circ} \mathrm{N}$ are consistent with the demographics, topography, and land use of the northern parts of England and of Northern Ireland; these areas are less populated than the southern parts, host the hills and mountains of the Lake District and the North Pennines, and the land use consists largely of grasslands. The combination of these factors (lower density of anthropogenic sources and higher density of biogenic sinks compared to southern parts of the UK) can explain the net negative fluxes of $\mathrm{CO}_{2}$ measured during the daytime in spring and summer. Whilst the observed lower emissions of $\mathrm{CO}_{2}$ in the northern parts of the spatial domain are consis- 

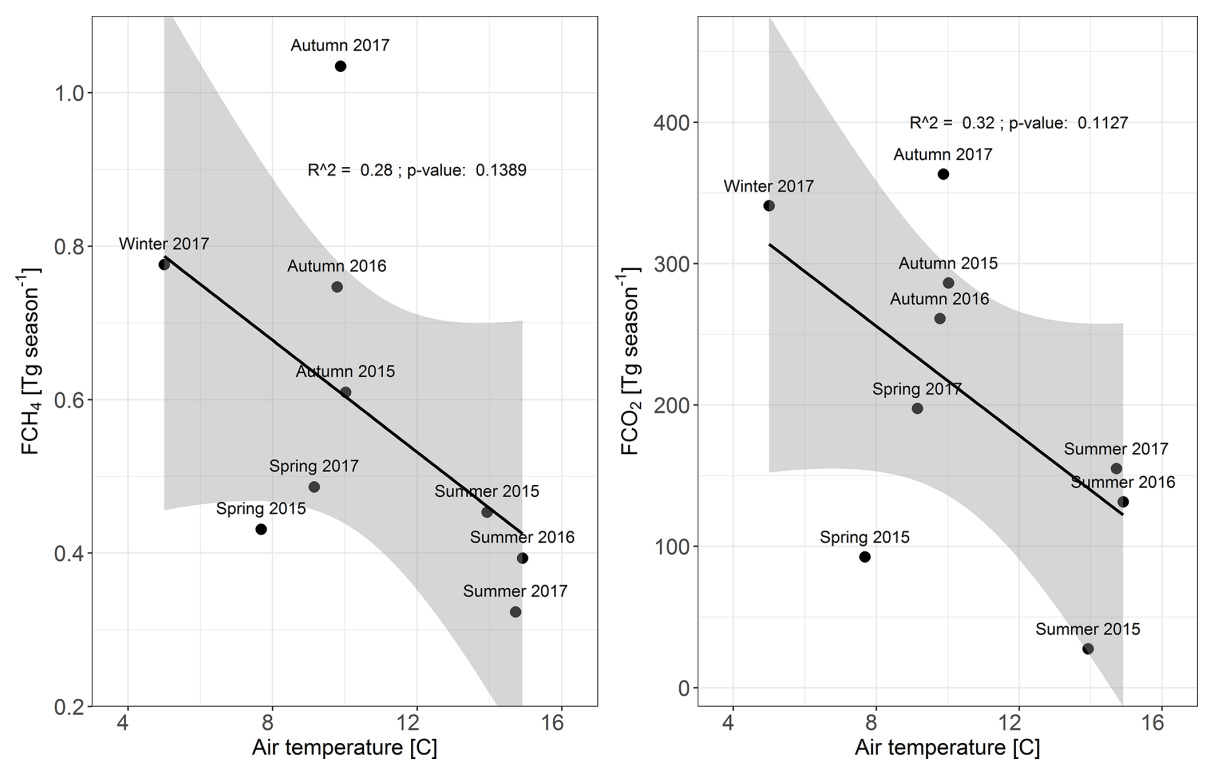

Figure 12. Seasonal budgets of $\mathrm{CH}_{4}$ and $\mathrm{CO}_{2}$ as a function of mean UK air temperature derived from ca. 250 synoptic stations (source: Met Office, 2018). The shaded area represents the $95 \%$ confidence intervals of the linear regressions.
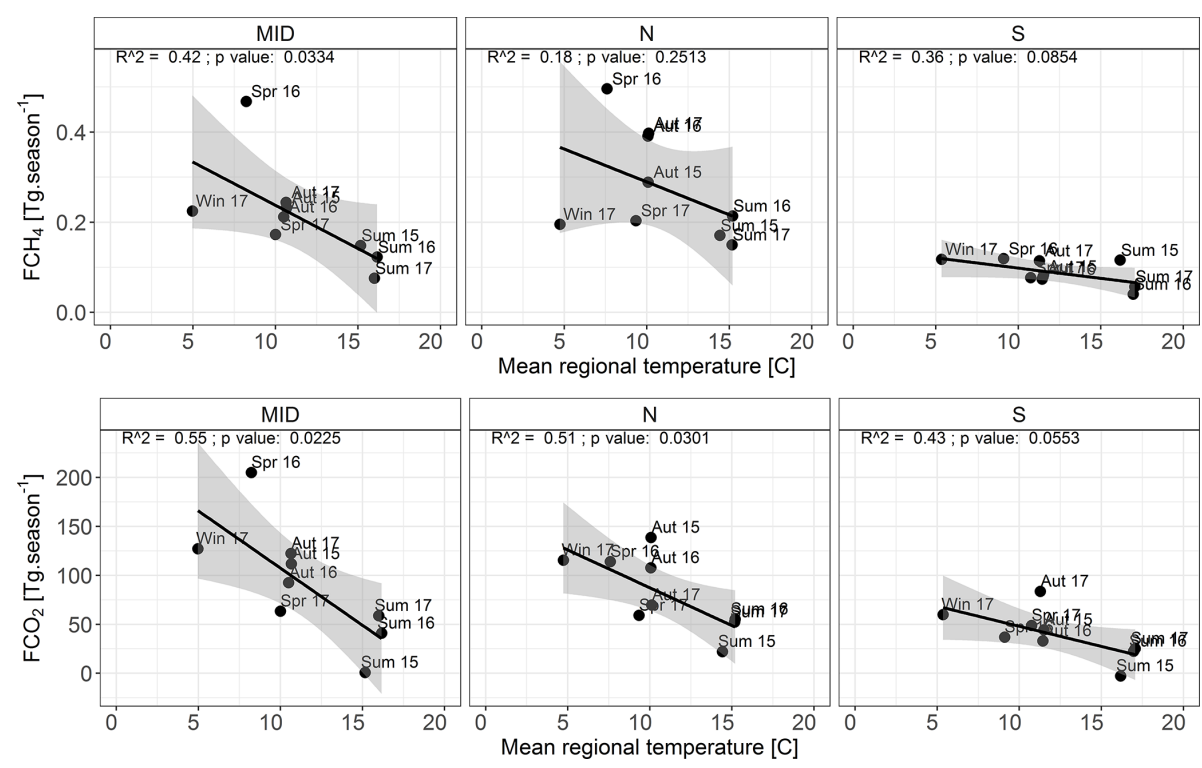

Figure 13. Seasonal fluxes of $\mathrm{CH}_{4}$ and $\mathrm{CO}_{2}$ estimated by mass balance from concentration measurements on board the ferry as a function of mean regional air temperature (source: Met Office, 2018). The data are presented for three latitudinal regions denoted MID, N, and S. The MID region spans the latitude range $52.8-54.2^{\circ} \mathrm{N}, \mathrm{N}$ spans $54.2-56.1^{\circ} \mathrm{N}$, and S spans $52.0-52.8^{\circ} \mathrm{N}$. The shaded area represents the $95 \%$ confidence intervals of the linear regressions.

tent with the spatial distribution of emissions from NAEI data (NAEI, 2018a), Polson et al. (2011) reported substantial summertime emissions from Ireland and Northern Ireland which should cancel out the sink terms in northern England when integrating along a latitude bin. The fact that negative and very low summer emissions were derived by the ferry mass balance approach could indicate that measurements on board the ferry were more sensitive to sources and sinks in the east- ern parts of the domain sampled because of (a) violation of the simplifying assumption that there is no loss of mass out of the domain, (b) imperfect vertical mixing, or (c) local air circulation which would not have been resolved by the HYSPLIT air mass histories. Alternatively, the mass balance estimates are real and the high $\mathrm{CO}_{2}$ emissions assigned to Ireland in the aircraft inversion model are measurement arte- 
facts caused by the venting of the nocturnal boundary layer as postulated by Polson et al. (2011).

There was no statistically significant difference between day and night fluxes for $\mathrm{CH}_{4}$, which could be because (a) the major sources of this gas in the British Isles (livestock, including enteric fermentation and manure management, and waste-treatment-related emissions, including landfills and waste water; $52.8 \%$ and $39.1 \%$ of the total $\mathrm{CH}_{4}$ budget for the UK, respectively; BEIS, 2017) do not have marked diurnal cycles, (b) the mass balance approach could not resolve them, (c) the transit time of the air masses over the spatial domain blurred the potential differences between day and night emissions, or (d) the $\mathrm{CH}_{4}$ signal measured on the ferry was contaminated and did not reflect emissions from the land surface. Due to the temporal and spatial averaging carried out to derive emission estimates from the ferry measurements, and due to the diffuse spatial distribution of the dominant land sources of $\mathrm{CH}_{4}$, it seems likely that relatively small diurnal variations (e.g. studies indicate diurnal cycles in $\mathrm{CH}_{4}$ emissions from dairy farms and from landfills sites; Van der Zaag et al., 2014, and Borjesson and Svensson, 1997, respectively) would not be resolved by the mass balance approach.

At the seasonal timescale, the fluxes of $\mathrm{CH}_{4}$ and $\mathrm{CO}_{2}$ were both strongly correlated with UK natural gas usage (Fig. 11; BEIS, 2018); this provides confidence that the fluxes calculated by the mass balance approach can be related to physical emissions within the spatial domain and that the data filtering and quality control criteria excluded data points potentially contaminated by emissions from the ship. The statistically significant linear correlations between derived $\mathrm{CH}_{4}$ and $\mathrm{CO}_{2}$ fluxes and natural gas usage do not demonstrate causality, but suggest that the sources of these two GHGs within the domain sampled have seasonal dynamics similar to those of natural gas usage. However, both $\mathrm{CH}_{4}$ and $\mathrm{CO}_{2}$ emissions exhibited a weaker correlation with mean seasonal air temperature than with natural gas usage (Fig. 12), and this may indicate that natural gas consumption is a causal driver rather than a proxy for another underlying variable. Whilst it is reasonable to infer that both $\mathrm{CO}_{2}$ and $\mathrm{CH}_{4}$ would increase in line with an increasing demand for natural gas during the colder months, the NAEI (NAEI, 2018b) attributes only $15 \%$ of annual $\mathrm{CH}_{4}$ emissions to fuel-related sources (combustion and fugitive emissions); this does not tally with the $\sim 100 \%$ increase in $\mathrm{CH}_{4}$ emissions between winter and summer, which is accompanied by a similar increase in natural gas usage. An unexpectedly large diurnal and seasonal variability in the $\mathrm{CH}_{4}$ flux was observed from direct flux measurements above London (Helfter et al., 2016), and this suggested that pressure variations in the gas supply network in response to gas demand may have a significant impact on urban emissions. Fugitive emissions from the network may be underestimated in the NAEI.

Seasonality in methane emissions from landfills has also been reported, with higher emissions sometimes observed in winter and autumn (Borjesson and Svensson, 1997; Chan- ton and Liptay, 2000). The explanation for this is that net $\mathrm{CH}_{4}$ emissions from landfill emissions can be largely regulated by methane oxidation in the top layer of the landfill cover soil: oxidation is limited by soil temperature and the methane-oxidising potential decreases in autumn and winter because of lower soil temperatures, which results in an increase in methane emissions during the colder seasons. Riddick et al. (2017) reported a $71 \%$ winter-to-summer reduction in $\mathrm{CH}_{4}$ emissions from a waste treatment park near Haddenham, England. Central England has the largest densities of waste treatment and landfill sites, which might explain the statistically significant linear anti-correlation between seasonal $\mathrm{CH}_{4}$ emissions and mean air temperature found in this region (Fig. 13). This is a remarkable result, which demonstrates the merit of this simple mass balance approach. In the other two regions considered ( $\mathrm{N}$ and S, i.e. north and south of the central region denoted as MID), there was no compelling correlation between $\mathrm{CH}_{4}$ emissions and mean air temperature. This suggests that the dominant sources of this GHG in the $\mathrm{N}$ and $\mathrm{S}$ regions differ from the ones in the central region.

For $\mathrm{CO}_{2}$, the seasonal emissions had statistically significant correlations with mean air temperature in the central and northern regions, whilst the linear correlation was only marginally non-significant in the southern region. This is consistent with (a) the seasonality of natural gas usage (the NAEI attributes $\sim 50 \%$ of annual $\mathrm{CO}_{2}$ emissions to fuel combustion processes such as domestic and industrial gas usage; NAEI, 2018b) and (b) the seasonality of $\mathrm{CO}_{2}$ uptake by vegetation.

Contrary to our findings, the $\mathrm{UK} \mathrm{CH}_{4}$ emissions derived by inverse modelling using concentration data from four tall tower sites distributed across the UK and Ireland did not exhibit any clear seasonality over the period August 2012August 2014 (Ganesan et al., 2015), but the range of emissions ( 1.65 to $2.67 \mathrm{Tg}$ ) was consistent with the ferry measurements $(1.52 \pm 1.0$ to $3.56 \pm 0.32 \mathrm{Tg})$.

For $\mathrm{CH}_{4}$, all four annual budgets calculated using all the available data for the 2015-2017 period were consistent with the inventory values for the UK (excluding Scotland) and the Republic of Ireland, as well as with top-down modelling estimates (Table 3). Temporal data aggregation (i.e. not considering seasonality) increased the uncertainty on the final budget (36\% and $32 \%$ uncertainty for annual budgets derived with and without considering differences in day and night emissions compared to $12 \%$ and $19 \%$ for the budgets into which seasonality was factored) and it therefore seems that this approach should be discarded. The difference between the annual $\mathrm{CH}_{4}$ budgets calculated with and without day-night segregation but with seasonality was within the uncertainty of the individual estimates, and since we found no compelling evidence of diurnal trends, we arrive at $2.55 \pm 0.48 \mathrm{Tg} \mathrm{yr}^{-1}$ as our final estimate of the methane emissions from the UK (excluding Scotland) and the Republic of Ireland for the period 2015-2017. 
Following the same argument regarding temporal data aggregation, we derive an annual emission budget for $\mathrm{CO}_{2}$ of $881.0 \pm 125.8 \mathrm{Tg} \mathrm{yr}^{-1}$, which is the estimate obtained from seasonal budgets with day-night segregation because we found indications of diurnal trends in some parts of the spatial domain.

This value is more than twice the inventory estimate of 422.7 Tg, but contrarily to $\mathrm{CH}_{4}, \mathrm{CO}_{2}$ has significant biogenic sources (e.g. the $\mathrm{CO}_{2}$ exhaled by the 65 million-strong human population within the spatial domain considered is of the order of $18 \mathrm{Tg} \mathrm{yr}^{-1}$; Moriwaki and Kanda, 2004) and sinks (vegetation uptake) which are not accounted for by anthropogenic atmospheric emissions inventories; a direct comparison with the inventory is hence not possible. Polson et al. (2011) derived an annual budget for $\mathrm{CO}_{2}$ of $620 \pm$ $105 \mathrm{Tg} \mathrm{yr}^{-1}$ from a series of flights around Britain in the summer of 2005 and September 2006. Using only summer data, in order to emulate the temporal upscaling done by Polson, we arrive at an annual $\mathrm{CO}_{2}$ budget of $511 \pm 308 \mathrm{Tg} \mathrm{yr}^{-1}$, which agrees with the 2011 aircraft study within measurement uncertainty. Whilst the seasonality of $\mathrm{CO}_{2}$ emissions cannot be disregarded, comparing our summertime budgets with the aircraft study provides an independent validation of the ferry mass balance approach and gives us confidence in the method despite the simplifying assumptions that underpin it. Finally, we compared the ferry-derived summertime estimates for the southern region, filtered with a narrow 260$280^{\circ}$ wind direction window, to the fluxes of $\mathrm{CO}_{2}$ and $\mathrm{CH}_{4}$ obtained in 2012 by airborne measurements in the greater London area (O'Shea et al., 2014). The ferry fluxes of both gases $\left(\mathrm{CH}_{4}: 0.049 \pm 0.020 ; \mathrm{CO}_{2}: 24 \pm 15 \mathrm{Tg}\right.$ season $\left.^{-1}\right)$ compared reasonably well with the ones from the airborne campaign $\left(\mathrm{CH}_{4}: 0.034 \pm 0.002 ; \mathrm{CO}_{2}: 13.4 \pm 1.2 \mathrm{Tg}\right.$ season $\left.^{-1}\right)$, but clearly also include sources upwind and downwind of the greater London area. The uncertainty was large for both gases, which is unsurprising considering the length of the averaging period (summers of 2015 and 2016), but this comparison with another independent measurement further consolidates the confidence in the method and in the overall annual budgets for $\mathrm{CH}_{4}$ and $\mathrm{CO}_{2}$.

\section{Conclusions}

Applying a mass balance approach to continuous measurements of $\mathrm{CO}_{2}$ and $\mathrm{CH}_{4}$ in the outflow and using a ship of opportunity, we estimated the net annual emissions of $\mathrm{CH}_{4}$ from the UK (excluding Scotland) and the Republic of Ireland, averaged over the 2015-2017 period, to be $2.55 \pm$ $0.48 \mathrm{Tg}$, which is consistent with the combined $2.29 \mathrm{Tg}$ reported to the United Nations Framework Convention on Climate Change. The annual $\mathrm{CO}_{2}$ budget obtained by mass balance $(881.0 \pm 125.8 \mathrm{Tg})$ was more than twice the inventory value $(422.7 \mathrm{Tg})$, but a direct comparison is not possible for this gas because the atmospheric inventory only accounts for anthropogenic sources (BEIS, 2016). Instead we compared our $\mathrm{CO}_{2}$ budget estimate with previous airborne studies, one for the UK as a whole and the second one for the greater London area, and found good agreement with both. The mass balance approach presented here does not provide direct source apportionment information, but the latitudinal emission patterns observed for both $\mathrm{CH}_{4}$ and $\mathrm{CO}_{2}$ were generally consistent with known spatial distributions of sources and sinks. Assuming that the atmospheric emissions inventory captures all anthropogenic emissions, we estimate that the net biogenic component of the measured $\mathrm{CO}_{2}$ annual budget was $458.7 \mathrm{Tg}$, which corresponds to $52 \%$ of the total emissions. We detected marked seasonality in the emissions of both gases with lower values in the summer, and the seasonal budgets had statistically significant correlations with natural gas and mean air temperature. We attribute the twothirds decrease in $\mathrm{CO}_{2}$ emissions between winter and summer for $\mathrm{CO}_{2}$ to the superposition of the reduction in demand for fossil fuels and an increase in the biogenic sink during the summer. For $\mathrm{CH}_{4}$, we attribute the seasonal variability of the measured fluxes to natural gas consumption and to the waste management sector for which temperature has been shown to control the methane-oxidising potential of landfill cover soil and thereby the net emissions. With this study, we validated the atmospheric emissions inventory of $\mathrm{CH}_{4}$ for the UK (excluding Scotland) and Ireland, quantified the biogenic component of the annual $\mathrm{CO}_{2}$ budget, and derived seasonal emissions budgets for both gases. Finally, we demonstrated that $\mathrm{CH}_{4}$ emissions are strongly seasonal even at such a relatively large spatial scale, which highlights the importance of taking meteorological drivers such as air temperature into account in future bottom-up budgets.

Data availability. The datasets are currently in the process of being archived with the Centre for Environmental Data Analysis (CEDA; http://www.ceda.ac.uk, last access: 7 March 2019). They will be accessible from http: //catalogue.ceda.ac.uk/uuid/9a1295858ff14fc6acea73e356a8842c (GAUGE project team, 2015).

Supplement. The supplement related to this article is available online at: https://doi.org/10.5194/acp-19-3043-2019-supplement.

Author contributions. $\mathrm{CH}$ led the data analysis and writing of the paper with contributions from all co-authors. Furthermore, NM and MR provided the calibrated time series of gas concentrations measured on the ship and at the Mace Head site, respectively. SO'D led the "round robin" inter-calibration of analysers used within the wider GAUGE project, and MV carried out the WRF modelling. Finally, PP and EN advised on methodology and data interpretation. 
Competing interests. The authors declare that they have no conflict of interest.

Special issue statement. This article is part of the special issue "Greenhouse gAs Uk and Global Emissions (GAUGE) project (ACP/AMT inter-journal SI)". It is not associated with a conference.

Acknowledgements. The GAUGE project was funded by the UK Natural Environment Research Council under grant reference NE/K002449/1. This work was also supported by the Natural Environment Research Council award number NE/R016429/1 as part of the UK-SCAPE programme delivering National Capability.

We are grateful to DFDS Seaways for authorising the research activities on board the Rosyth-Zeebrugge commercial ferry, and we thank the captains and crews of the Longstone (now the Finnmerchant) and Finlandia Seaways for access to the ships and for assistance with the day-to-day research operations. We also acknowledge the contributions of Gerry Spain (NUIG), Victor Kazan (LSCE), and Damien Martin (EPA, Ireland) for the maintenance of the analysers at the Mace Head measurement station.

Edited by: Dominik Brunner

Reviewed by: two anonymous referees

\section{References}

Allen, G.: Rebalancing the global methane budget, Nature, 538, 4648, https://doi.org/10.1038/538046a, 2016.

Bakwin, P. S., Tans, P. P., Zhao, C. L., Ussler, W., and Quesnell, E.: Measurements of carbon-dioxide on a very tall tower, Tellus B, 47, 535-549, https://doi.org/10.1034/j.1600-0889.47.issue5.2.x, 1995.

Balzarini, A., Angelini, F., Ferrero, L., Moscatelli, M., Perrone, M. G., Pirovano, G., Riva, G. M., Sangiorgi, G., Toppetti, A. M., Gobbi, G. P., and Bolzacchini, E.: Sensitivity analysis of PBL schemes by comparing WRF model and experimental data, Geosci. Model Dev. Discuss., 7, 6133-6171, https://doi.org/10.5194/gmdd-7-6133-2014, 2014.

Banks, R. F., Tiana-Alsina, J., Baldasano, J. M., Rocadenbosch, F., Papayannis, A., Solomos, S., and Tzanis, C. G.: Sensitivity of boundary-layer variables to PBL schemes in the WRF model based on surface meteorological observations, LIDAR, and radiosondes during the HygrA-CD campaign, Atmos. Res., 176177, 185-201, https://doi.org/10.1016/j.atmosres.2016.02.024, 2016.

BEIS (Department for Business, Energy and Industrial Strategy): UK Emission Mapping Methodology, available at: https://uk-air.defra.gov.uk/assets/documents/reports/cat07/ 1812061112_MappingMethodology-for-NAEI-2016.pdf (last access: 23 January 2019), 2016.

BEIS (Department for Business, Energy and Industrial Strategy): UK Greenhouse Gas Inventory, 1990 to 2015, in: Annual Report for Submission under the Framework Convention on Climate Change, Issue 2, available at: http://naei.beis.gov.uk/reports/ reports?report_id=958 (last access: 5 June 2018), 2017.
BEIS (Department for Business, Energy and Industrial Strategy): Natural Gas Supply and Consumption, Table ET 4.1, available at: https://www.gov.uk/government/statistics/ gas-section-4-energy-trends, last access: 5 June 2018.

Bergamaschi, P., Corazza, M., Karstens, U., Athanassiadou, M., Thompson, R. L., Pison, I., Manning, A. J., Bousquet, P., Segers, A., Vermeulen, A. T., Janssens-Maenhout, G., Schmidt, M., Ramonet, M., Meinhardt, F., Aalto, T., Haszpra, L., Moncrieff, J., Popa, M. E., Lowry, D., Steinbacher, M., Jordan, A., O'Doherty, S., Piacentino, S., and Dlugokencky, E.: Top-down estimates of European $\mathrm{CH}_{4}$ and $\mathrm{N}_{2} \mathrm{O}$ emissions based on four different inverse models, Atmos. Chem. Phys., 15, 715-736, https://doi.org/10.5194/acp-15-715-2015, 2015.

Biraud, S., Ciais, P., Ramonet, M., Simmonds, P., Kazan, V., Monfray, P., O’Doherty, S., Spain, T. G., and Jennings, S. G.: European greenhouse gas emissions estimated from continuous atmospheric measurements and radon 222 at Mace Head, Ireland, J. Geophys. Res.-Atmos., 105, 1351-1366, https://doi.org/10.1029/1999jd900821, 2000.

Bohnenstengel, S. I., Belcher, S. E., Aiken, A., Allan, J. D., Allen, G., Bacak, A., Bannan, T. J., Barlow, J. F., Beddows, D. C. S., Bloss, W. J., Booth, A. M., Chemel, C., Coceal, O., Di Marco, C. F., Dubey, M. K., Faloon, K. H., Fleming, Z. L., Furger, M., Gietl, J. K., Graves, R. R., Green, D. C., Grimmond, C. S. B., Halios, C. H., Hamilton, J. F., Harrison, R. M., Heal, M. R., Heard, D. E., Helfter, C., Herndon, S. C., Holmes, R. E., Hopkins, J. R., Jones, A. M., Kelly, F. J., Kotthaus, S., Langford, B., Lee, J. D., Leigh, R. J., Lewis, A. C., Lidster, R. T., LopezHilfiker, F. D., McQuaid, J. B., Mohr, C., Monks, P. S., Nemitz, E., Ng, N. L., Percival, C. J., Prevot, A. S. H., Ricketts, H. M. A., Sokhi, R., Stone, D., Thornton, J. A., Tremper, A. H., Valach, A. C., Visser, S., Whalley, L. K., Williams, L. R., Xu, L., Young, D. E., and Zotter, P.: Meteorology, air quality, and health in London the ClearfLo project, B. Am. Meteorol. Soc., 96, 779-804, https://doi.org/10.1175/bams-d-12-00245.1, 2015.

Borjesson, G. and Svensson, B. H.: Seasonal and diurnal methane emissions from a landfill and their regulation by methane oxidation, Waste Manage. Res., 15, 33-54, https://doi.org/10.1177/0734242x9701500104, 1997.

Cambaliza, M. O. L., Shepson, P. B., Caulton, D. R., Stirm, B., Samarov, D., Gurney, K. R., Turnbull, J., Davis, K. J., Possolo, A., Karion, A., Sweeney, C., Moser, B., Hendricks, A., Lauvaux, T., Mays, K., Whetstone, J., Huang, J., Razlivanov, I., Miles, N. L., and Richardson, S. J.: Assessment of uncertainties of an aircraft-based mass balance approach for quantifying urban greenhouse gas emissions, Atmos. Chem. Phys., 14, 9029-9050, https://doi.org/10.5194/acp-14-9029-2014, 2014.

Cambaliza, M. O. L., Shepson, P. B., Bogner, J., Caulton, D. R., Stirm, B., Sweeney, C., Montzka, S. A., Gurney, K. R., Spokas, K., Salmon, O. E., Lavoie, T. N., Hendricks, A., Mays, K., Turnbull, J., Miller, B. R., Lauvaux, T., Davis, K., Karion, A., Moser, B., Miller, C., Obermeyer, C., Whetstone, J., Prasad, K., Miles, N., and Richardson, S.: Quantification and source apportionment of the methane emission flux from the city of Indianapolis, Elementa-Science of the Anthropocene, 3, 000037, https://doi.org/10.12952/journal.elementa.000037, 2015.

Chanton, J. and Liptay, K.: Seasonal variation in methane oxidation in a landfill cover soil as determined by an in situ 
stable isotope technique, Global Biogeochem. Cy., 14, 51-60, https://doi.org/10.1029/1999gb900087, 2000.

Dengel, S., Levy, P. E., Grace, J., Jones, S. K., and Skiba, U. M.: Methane emissions from sheep pasture, measured with an openpath eddy covariance system, Glob. Change Biol., 17, 35243533, https://doi.org/10.1111/j.1365-2486.2011.02466.x, 2011.

Derwent, R. G., Ryall, D. B., Manning, A., Simmonds, P. G., O'Doherty, S., Biraud, S., Ciais, P., Ramonet, M., and Jennings, S. G.: Continuous observations of carbon dioxide at Mace Head, Ireland from 1995 to 1999 and its net European ecosystem exchange, Atmos. Environ., 36, 2799-2807, https://doi.org/10.1016/s1352-2310(02)00203-0, 2002.

Dlugokencky, E. J., Nisbet, E. G., Fisher, R., and Lowry, D.: Global atmospheric methane: Budget, changes and dangers, Philos. T. Roy. Soc. A, 369, 2058-2072, https://doi.org/10.1098/rsta.2010.0341, 2011.

Erkkilä, K.-M., Ojala, A., Bastviken, D., Biermann, T., Heiskanen, J. J., Lindroth, A., Peltola, O., Rantakari, M., Vesala, T., and Mammarella, I.: Methane and carbon dioxide fluxes over a lake: comparison between eddy covariance, floating chambers and boundary layer method, Biogeosciences, 15, 429-445, https://doi.org/10.5194/bg-15-429-2018, 2018.

EPA (Environment Protection Agency): Ireland National Inventory Report 2017: Greenhouse Gas Emissions 19902015; available at: https://unfccc.int/process/transparency-andreporting/reporting-and-review-under-the-convention (last access: 28 May 2018), 2017.

Felber, R., Münger, A., Neftel, A., and Ammann, C.: Eddy covariance methane flux measurements over a grazed pasture: effect of cows as moving point sources, Biogeosciences, 12, 3925-3940, https://doi.org/10.5194/bg-12-3925-2015, 2015.

Feng, L., Palmer, P. I., Bösch, H., and Dance, S.: Estimating surface $\mathrm{CO}_{2}$ fluxes from space-borne $\mathrm{CO}_{2}$ dry air mole fraction observations using an ensemble Kalman Filter, Atmos. Chem. Phys., 9, 2619-2633, https://doi.org/10.5194/acp-9-2619-2009, 2009.

Feng, L., Palmer, P. I., Yang, Y., Yantosca, R. M., Kawa, S. R., Paris, J.-D., Matsueda, H., and Machida, T.: Evaluating a 3-D transport model of atmospheric $\mathrm{CO}_{2}$ using ground-based, aircraft, and space-borne data, Atmos. Chem. Phys., 11, 27892803, https://doi.org/10.5194/acp-11-2789-2011, 2011.

Fowler, D., Hargreaves, K. J., Choularton, T. W., Gallagher, M. W., Simpson, T., and Kaye, A.: Measurements of regional $\mathrm{CH}_{4}$ emissions in the UK using boundary layer budget methods, Energ. Convers. Manage., 37, 769-775, https://doi.org/10.1016/01968904(95)00254-5, 1996.

Gallagher, M. W., Choularton, T. W., Bower, K. N., Stromberg, I. M., Beswick, K. M., Fowler, D., and Hargreaves, K. J.: Measurements of methane fluxes on the landscape scale from a wetland area in north Scotland, Atmos. Environ., 28, 2421-2430, https://doi.org/10.1016/1352-2310(94)90394-8, 1994.

Ganesan, A. L., Manning, A. J., Grant, A., Young, D., Oram, D. E., Sturges, W. T., Moncrieff, J. B., and O'Doherty, S.: Quantifying methane and nitrous oxide emissions from the UK and Ireland using a national-scale monitoring network, Atmos. Chem. Phys., 15, 6393-6406, https://doi.org/10.5194/acp-156393-2015, 2015.

GAUGE project team: GAUGE (Greenhouse gAs UK and Global Emissions) project: Ground based and airborne atmospheric measurement data collection, Centre for Envi- ronmental Data Analysis, available at: http://catalogue.ceda. ac.uk/uuid/9a1295858ff14fc6acea73e356a8842c (last access: 7 March 2019), 2015

Gioli, B., Toscano, P., Lugato, E., Matese, A., Miglietta, F., Zaldei, A., and Vaccari, F. P.: Methane and carbon dioxide fluxes and source partitioning in urban areas: The case study of Florence, Italy, Environ. Pollut., 164, 125-131, https://doi.org/10.1016/j.envpol.2012.01.019, 2012.

Gregg, J. S., Andres, R. J., and Marland, G.: China: Emissions pattern of the world leader in $\mathrm{CO}_{2}$ emissions from fossil fuel consumption and cement production, Geophys. Res. Lett., 35, L08806, https://doi.org/10.1029/2007g1032887, 2008.

Gregg, M.: Uncertainties in accounting for $\mathrm{CO}_{2}$ from fossil fuels, J. Indust. Ecol., 12, 136-139, https://doi.org/10.1111/j.15309290.2008.00014.x, 2008.

Guan, D. B., Liu, Z., Geng, Y., Lindner, S., and Hubacek, K.: The gigatonne gap in China's carbon dioxide inventories, Nat. Clim. Change, 2, 672-675, https://doi.org/10.1038/nclimate1560, 2012.

Hazan, L., Tarniewicz, J., Ramonet, M., Laurent, O., and Abbaris, A.: Automatic processing of atmospheric $\mathrm{CO}_{2}$ and $\mathrm{CH}_{4}$ mole fractions at the ICOS Atmosphere Thematic Centre, Atmos. Meas. Tech., 9, 4719-4736, https://doi.org/10.5194/amt-9-47192016, 2016.

Helfter, C., Famulari, D., Phillips, G. J., Barlow, J. F., Wood, C. R., Grimmond, C. S. B., and Nemitz, E.: Controls of carbon dioxide concentrations and fluxes above central London, Atmos. Chem. Phys., 11, 1913-1928, https://doi.org/10.5194/acp11-1913-2011, 2011.

Helfter, C., Tremper, A. H., Halios, C. H., Kotthaus, S., Bjorkegren, A., Grimmond, C. S. B., Barlow, J. F., and Nemitz, E.: Spatial and temporal variability of urban fluxes of methane, carbon monoxide and carbon dioxide above London, UK, Atmos. Chem. Phys., 16, 10543-10557, https://doi.org/10.5194/acp-16-105432016, 2016.

Hiller, R. V., Neininger, B., Brunner, D., Gerbig, C., Bretscher, D., Kuenzle, T., Buchmann, N., and Eugster, W.: Aircraft-based $\mathrm{CH}_{4}$ flux estimates for validation of emissions from an agriculturally dominated area in Switzerland, J. Geophys. Res.-Atmos., 119, 4874-4887, https://doi.org/10.1002/2013jd020918, 2014.

Hong, S.-Y., Noh, Y., and Dudhia, J.: A New Vertical Diffusion Package with an Explicit Treatment of Entrainment Processes, Mon. Weather Rev., 134, 2318-2341, https://doi.org/10.1175/mwr3199.1, 2006.

Hu, X. M., Nielsen-Gammon, J. W., and Zhang, F.: Evaluation of Three Planetary Boundary Layer Schemes in the WRF Model, J. Appl. Meteorol., 49, 1831-1844, https://doi.org/10.1175/2010JAMC2432.1, 2010.

IPCC (International Panel on Climate Change): 2006 IPCC Guidelines for National Greenhouse Gas Inventories, available at: https://www.ipcc-nggip.iges.or.jp/public/2006gl/vol1.html (last access: 12 June 2018), 2006.

Karion, A., Sweeney, C., Petron, G., Frost, G., Hardesty, R. M., Kofler, J., Miller, B. R., Newberger, T., Wolter, S., Banta, R., Brewer, A., Dlugokencky, E., Lang, P., Montzka, S. A., Schnell, R., Tans, P., Trainer, M., Zamora, R., and Conley, S.: Methane emissions estimate from airborne measurements over a Western United States natural gas field, Geophys. Res. Lett., 40, 43934397, https://doi.org/10.1002/grl.50811, 2013. 
Karion, A., Sweeney, C., Kort, E. A., Shepson, P. B., Brewer, A., Cambaliza, M., Conley, S. A., Davis, K., Deng, A. J., Hardesty, M., Herndon, S. C., Lauvaux, T., Lavoie, T., Lyon, D., Newberger, T., Petron, G., Rella, C., Smith, M., Wolter, S., Yacovitch, T. I., and Tans, P.: Aircraft-based estimate of total methane emissions from the Barnett shale region, Environ. Sci. Technol., 49, 8124-8131, https://doi.org/10.1021/acs.est.5b00217, 2015.

Kirschke, S., Bousquet, P., Ciais, P., Saunois, M., Canadell, J. G., Dlugokencky, E. J., Bergamaschi, P., Bergmann, D., Blake, D. R., Bruhwiler, L., Cameron-Smith, P., Castaldi, S., Chevallier, F., Feng, L., Fraser, A., Heimann, M., Hodson, E. L., Houweling, S., Josse, B., Fraser, P. J., Krummel, P. B., Lamarque, J.F., Langenfelds, R. L., Le Quéré, C., Naik, V., O'Doherty, S., Palmer, P. I., Pison, I., Plummer, D., Poulter, B., Prinn, R. G., Rigby, M., Ringeval, B., Santini, M., Schmidt, M., Shindell, D. T., Simpson, I. J., Spahni, R., Steele, L. P., Strode, S. A., Sudo, K., Szopa, S., van der Werf, G. R., Voulgarakis, A., van Weele, M., Weiss, R. F., Williams, J. E., and Zeng, G.: Three decades of global methane sources and sinks, Nat. Geosci., 6, 813-823, https://doi.org/10.1038/ngeo1955, 2013.

Marland, G.: Emissions accounting China's uncertain $\mathrm{CO}_{2}$ emissions, Nat. Clim. Change, 2, 645-646, https://doi.org/10.1038/nclimate1670, 2012.

Mays, K. L., Shepson, P. B., Stirm, B. H., Karion, A., Sweeney, C., and Gurney, K. R.: Aircraft-based measurements of the carbon footprint of Indianapolis, Environ. Sci. Technol., 43, 7816-7823, https://doi.org/10.1021/es901326b, 2009.

Meijide, A., Manca, G., Goded, I., Magliulo, V., di Tommasi, P., Seufert, G., and Cescatti, A.: Seasonal trends and environmental controls of methane emissions in a rice paddy field in Northern Italy, Biogeosciences, 8, 3809-3821, https://doi.org/10.5194/bg8-3809-2011, 2011.

Met Éireann: Meteorological data from Mace Head station, Met Éireann Data is licensed under a Creative Commons AttributionShareAlike 4.0 International Licence, available at: http://www. met.ie/climate-request/, last access: 30 March 2018.

Met Office: UK and Regional Series, UK Open Government Licence for Public Sector Information v3.0 @ Crown Copyright 2018, available at: https://www.metoffice.gov.uk/climate/ uk/summaries/datasets, last access: 5 June 2018.

Miller, S. M., Wofsy, S. C., Michalak, A. M., Kort, E. A., Andrews, A. E., Biraud, S. C., Dlugokencky, E. J., Eluszkiewicz, J., Fischer, M. L., Janssens-Maenhout, G., Miller, B. R., Miller, J. B., Montzka, S. A., Nehrkorn, T., and Sweeney, C.: Anthropogenic emissions of methane in the United States, P. Natl. Acad. Sci. USA, 110, 20018-20022, https://doi.org/10.1073/pnas.1314392110, 2013.

Moriwaki, R. and Kanda, M.: Seasonal and diurnal fluxes of radiation, heat, water vapor, and carbon dioxide over a suburban area, J. Appl. Meteorol., 43, 1700-1710, https://doi.org/10.1175/jam2153.1, 2004.

NAEI (National Atmospheric Emissions Inventory): UK Emissions Interactive Maps, available at: http://naei.beis.gov.uk/data/ gis-mapping, last access: 8 August 2018a.

NAEI (National Atmospheric Emissions Inventory): Greenhouse gas inventories for England, Scotland, Wales \& Northern Ireland: 1990-2016, available at: http://naei.beis.gov.uk/reports/reports? report_id=958, last access: 12 June $2018 \mathrm{~b}$.
National Centers for Environmental Prediction/National Weather Service/NOAA/U.S.: Department of Commerce (2000), NCEP FNL Operational Model Global Tropospheric Analyses, continuing from July 1999, Research Data Archive at the National Center for Atmospheric Research, Computational and Information Systems Laboratory, Boulder, Colo, https://doi.org/10.5065/D6M043C6, 2000 (updated daily).

Nicolini, G., Castaldi, S., Fratini, G., and Valentini, R.: A literature overview of micrometeorological $\mathrm{CH}_{4}$ and $\mathrm{N}_{2} \mathrm{O}$ flux measurements in terrestrial ecosystems, Atmos. Environ., 81, 311-319, https://doi.org/10.1016/j.atmosenv.2013.09.030, 2013

Nisbet, E. G. and Weiss, R.: Top-down versus bottom-up, Science, 328, 1241-1243, https://doi.org/10.1126/science.1189936, 2010.

Nisbet, E. G., Dlugokencky, E. J., Manning, M. R., Lowry, D., Fisher, R. E., France, J. L., Michel, S. E., Miller, J. B., White, J. W. C., Vaughn, B., Bousquet, P., Pyle, J. A., Warwick, N. J., Cain, M., Brownlow, R., Zazzeri, G., Lanoisellé, M., Manning, A. C., Gloor, E., Worthy, D. E. J., Brunke, E.-G., Labuschagne, C., Wolff, E. W., and Ganesan, A. L.: Rising atmospheric methane: 2007-2014 growth and isotopic shift, Global Biogeochem. Cy. 30, 1356-1370, https://doi.org/10.1002/2016GB005406, 2016.

NOAA Air Resources Laboratory: HYSPLIT trajectory model, available at: https://www.ready.noaa.gov/HYSPLIT.php, last access: 9 September 2018.

Oney, B., Henne, S., Gruber, N., Leuenberger, M., Bamberger, I., Eugster, W., and Brunner, D.: The CarboCount $\mathrm{CH}$ sites: characterization of a dense greenhouse gas observation network, Atmos. Chem. Phys., 15, 11147-11164, https://doi.org/10.5194/acp-15-11147-2015, 2015.

O'Shea, S. J., Allen, G., Fleming, Z. L., Bauguitte, S. J. B., Percival, C. J., Gallagher, M. W., Lee, J., Helfter, C., and Nemitz, E.: Area fluxes of carbon dioxide, methane, and carbon monoxide derived from airborne measurements around Greater London: A case study during summer 2012, J. Geophys. Res.-Atmos., 119, 4940-4952, https://doi.org/10.1002/2013jd021269, 2014.

Palmer, P. I., O’Doherty, S., Allen, G., Bower, K., Bösch, H., Chipperfield, M. P., Connors, S., Dhomse, S., Feng, L., Finch, D. P., Gallagher, M. W., Gloor, E., Gonzi, S., Harris, N. R. P., Helfter, C., Humpage, N., Kerridge, B., Knappett, D., Jones, R. L., Le Breton, M., Lunt, M. F., Manning, A. J., Matthiesen, S., Muller, J. B. A., Mullinger, N., Nemitz, E., O'Shea, S., Parker, R. J., Percival, C. J., Pitt, J., Riddick, S. N., Rigby, M., Sembhi, H., Siddans, R., Skelton, R. L., Smith, P., Sonderfeld, H., Stanley, K., Stavert, A. R., Wenger, A., White, E., Wilson, C., and Young, D.: A measurement-based verification framework for UK greenhouse gas emissions: an overview of the Greenhouse gAs Uk and Global Emissions (GAUGE) project, Atmos. Chem. Phys., 18, 11753-11777, https://doi.org/10.5194/acp-18-117532018, 2018.

Pawlak, W. and Fortuniak, K.: Eddy covariance measurements of the net turbulent methane flux in the city centre - results of 2-year campaign in Lódz, Poland, Atmos. Chem. Phys., 16, 8281-8294, https://doi.org/10.5194/acp-16-8281-2016, 2016.

Pawlak, W., Fortuniak, K., Siedlecki, M., and Zielinski, M.: Urban - wetland contrast in turbulent exchange of methane, Atmos. Environ., 145, 176-191, https://doi.org/10.1016/j.atmosenv.2016.09.036, 2016.

Peltola, O., Hensen, A., Helfter, C., Belelli Marchesini, L., Bosveld, F. C., van den Bulk, W. C. M., Elbers, J. A., Haa- 
panala, S., Holst, J., Laurila, T., Lindroth, A., Nemitz, E., Röckmann, T., Vermeulen, A. T., and Mammarella, I.: Evaluating the performance of commonly used gas analysers for methane eddy covariance flux measurements: the InGOS intercomparison field experiment, Biogeosciences, 11, 3163-3186, https://doi.org/10.5194/bg-11-3163-2014, 2014.

Peltola, O., Hensen, A., Marchesini, L. B., Helfter, C., Bosveld, F. C., van den Bulk, W. C. M., Haapanala, S., van Huissteden, J., Laurila, T., Lindroth, A., Nemitz, E., Rockmann, T., Vermeulen, A. T., and Mammarella, I.: Studying the spatial variability of methane flux with five eddy covariance towers of varying height, Agr. Forest Meteorol., 214, 456-472, https://doi.org/10.1016/j.agrformet.2015.09.007, 2015.

Peters, G. P., Marland, G., Le Quéré, C., Boden, T., Canadell, J. G., and Raupach, M. R.: Rapid growth in $\mathrm{CO}_{2}$ emissions after the 2008-2009 global financial crisis, Nat. Clim. Change, 2, 2-4, https://doi.org/10.1038/nclimate1332, 2011.

Podgrajsek, E., Sahlee, E., and Rutgersson, A.: Diurnal cycle of lake methane flux, J. Geophys. Res.-Biogeo., 119, 236-248, https://doi.org/10.1002/2013jg002327, 2014.

Polson, D., Fowler, D., Nemitz, E., Skiba, U., McDonald, A., Famulari, D., Di Marco, C., Simmons, I., Weston, K., Purvis, R., Coe, H., Manning, A. J., Webster, H., Harrison, M., O'Sullivan, D., Reeves, C., and Oram, D.: Estimation of spatial apportionment of greenhouse gas emissions for the UK using boundary layer measurements and inverse modelling technique, Atmos. Environ., 45, 1042-1049, https://doi.org/10.1016/j.atmosenv.2010.10.011, 2011.

Ramonet, M., Ciais, P., Aalto, T., Aulagnier, C., Chevallier, F., Cipriano, D., Conway, T. J., Haszpra, L., Kazan, V., Meinhardt, F., Paris, J. D., Schmidt, M., Simmonds, P., Xueref-Remy, I., and Necki, J. N.: A recent build-up of atmospheric $\mathrm{CO}_{2}$ over Europe. Part 1: Observed signals and possible explanations, Tellus B, 62, 1-13, https://doi.org/10.1111/j.1600-0889.2009.00442.x, 2010.

Riddick, S. N., Connors, S., Robinson, A. D., Manning, A. J., Jones, P. S. D., Lowry, D., Nisbet, E., Skelton, R. L., Allen, G., Pitt, J., and Harris, N. R. P.: Estimating the size of a methane emission point source at different scales: from local to landscape, Atmos. Chem. Phys., 17, 7839-7851, https://doi.org/10.5194/acp17-7839-2017, 2017.

Rigby, M., Prinn, R. G., Fraser, P. J., Simmonds, P. G., Langenfelds, R. L., Huang, J., Cunnold, D. M., Steele, L. P., Krummel, P. B., Weiss, R. F., O'Doherty, S., Salameh, P. K., Wang, H. J., Harth, C. M., Muehle, J., and Porter, L. W.: Renewed growth of atmospheric methane, Geophys. Res. Lett., 35, L22805, https://doi.org/10.1029/2008g1036037, 2008.

Rigby, M., Montzka, S. A., Prinn, R. G., White, J. W. C., Young, D., O’Doherty, S., Lunt, M. F., Ganesan, A. L., Manning, A. J., Simmonds, P. G., Salameh, P. K., Harth, C. M., Mühle, J., Weiss, R. F., Fraser, P. J., Steele, L. P., Krummel, P. B., McCulloch, A., and Park, S.: Role of atmospheric oxidation in recent methane growth, P. Natl. Acad. Sci. USA, 114, 5373-5377, https://doi.org/10.1073/pnas.1616426114, 2017.

Salvador, N., Ayres, A. G., Santiago, A., Albuquerque, T. T. A., Neyval C. Reis Jr., Santos, J. M., Landulfo, E., Moreira, G., Lopes, F., Held, G., and Moreira, D. M.: Study of the Thermal Internal Boundary Layer in Sea Breeze Conditions Using Different Parameterizations: Application of the WRF Model in the Greater Vitória Region, Rev. Bras. Meteorol., 31, 593-609, https://doi.org/10.1590/0102-7786312314b20150093, 2016.

Saunois, M., Bousquet, P., Poulter, B., Peregon, A., Ciais, P., Canadell, J. G., Dlugokencky, E. J., Etiope, G., Bastviken, D., Houweling, S., Janssens-Maenhout, G., Tubiello, F. N., Castaldi, S., Jackson, R. B., Alexe, M., Arora, V. K., Beerling, D. J., Bergamaschi, P., Blake, D. R., Brailsford, G., Brovkin, V., Bruhwiler, L., Crevoisier, C., Crill, P., Covey, K., Curry, C., Frankenberg, C., Gedney, N., Höglund-Isaksson, L., Ishizawa, M., Ito, A., Joos, F., Kim, H.-S., Kleinen, T., Krummel, P., Lamarque, J.-F., Langenfelds, R., Locatelli, R., Machida, T., Maksyutov, S., McDonald, K. C., Marshall, J., Melton, J. R., Morino, I., Naik, V., O'Doherty, S., Parmentier, F.-J. W., Patra, P. K., Peng, C., Peng, S., Peters, G. P., Pison, I., Prigent, C., Prinn, R., Ramonet, M., Riley, W. J., Saito, M., Santini, M., Schroeder, R., Simpson, I. J., Spahni, R., Steele, P., Takizawa, A., Thornton, B. F., Tian, H., Tohjima, Y., Viovy, N., Voulgarakis, A., van Weele, M., van der Werf, G. R., Weiss, R., Wiedinmyer, C., Wilton, D. J., Wiltshire, A., Worthy, D., Wunch, D., Xu, X., Yoshida, Y., Zhang, B., Zhang, Z., and Zhu, Q.: The global methane budget 2000-2012, Earth Syst. Sci. Data, 8, 697-751, https://doi.org/10.5194/essd-8-697-2016, 2016.

Schwietzke, S., Sherwood, O. A., Bruhwiler, L. M. P., Miller, J. B., Etiope, G., Dlugokencky, E. J., Michel, S. E., Arling, V. A., Vaughn, B. H., White, J. W. C., and Tans, P. P.: Upward revision of global fossil fuel methane emissions based on isotope database, Nature, 538, 88-91, https://doi.org/10.1038/nature19797, 2016.

Skamarock, W., Klemp, J., Dudhia, J., Gill, D., Barker, D., Duda, M., Huang, X.-Y., Wang, W., and J., P.: A description of the advanced research WRF version 3, NCAR Technical Note, NCAR/TN-475+STR, Colorado, 2008.

Stanley, K. M., Grant, A., O’Doherty, S., Young, D., Manning, A. J., Stavert, A. R., Spain, T. G., Salameh, P. K., Harth, C. M., Simmonds, P. G., Sturges, W. T., Oram, D. E., and Derwent, R. G.: Greenhouse gas measurements from a UK network of tall towers: technical description and first results, Atmos. Meas. Tech., 11, 1437-1458, https://doi.org/10.5194/amt-11-1437-2018, 2018.

Stavert, A. R., O’Doherty, S., Stanley, K., Young, D., Manning, A. J., Lunt, M. F., Rennick, C., and Arnold, T.: UK greenhouse gas measurements at two new tall towers for aiding emissions verification, Atmos. Meas. Tech. Discuss., https://doi.org/10.5194/amt-2018-140, in review, 2018.

Steele, C. J., Dorling, S. R., von Glasow, R., and Bacon, J.: Idealized WRF model sensitivity simulations of sea breeze types and their effects on offshore windfields, Atmos. Chem. Phys., 13, 443461, https://doi.org/10.5194/acp-13-443-2013, 2013.

Steele, C. J., Dorling, S. R., von Glasow, R., and Bacon, J., Modelling sea-breeze climatologies and interactions on coasts in the southern North Sea: implications for offshore wind energy, Q. J. Roy. Meteor. Soc., 141, 1821-1835, https://doi.org/10.1002/qj.2484, 2015.

Turner, A. J., Frankenberg, C., Wennberg, P. O., and Jacob, D. J.: Ambiguity in the causes for decadal trends in atmospheric methane and hydroxyl, P. Natl. Acad. Sci. USA, 114, 5367-5372, https://doi.org/10.1073/pnas.1616020114, 2017.

Tyagi, B., Magliulo, V., Finardi, S., Gasbarra, D., Carlucci, P., Toscano, P., Zaldei, A., Riccio, A., Calori, G., D’Allura, A., and Gioli, B.: Performance Analysis of Planetary Bound- 
ary Layer Parameterization Schemes in WRF Modelling Set Up over Southern Italy, Amosphere-Basel, 9, 272, https://doi.org/10.3390/atmos9070272, 2018.

UNFCCC (United Nations Framework Convention on Climate Change): Report of the Conference of The Parties on its Nineteenth Session, Held in Warsaw from 11 to 23 November 2013, available at: https://unfccc.int/resource/docs/2013/cop19/ eng/10a03.pdf\#page=2 (last access: 5 June 2018), 2014.

Van der Zaag, A. C., Flesch, T. K., Desjardins, R. L., Balde, H., and Wright, T.: Measuring methane emissions from two dairy farms: Seasonal and manuremanagement effects, Agr. Forest Meteorol., 194, 259-267, https://doi.org/10.1016/j.agrformet.2014.02.003, 2014.

White, W. H., Anderson, J. A., Blumenthal, D. L., Husar, R. B., Gillani, N. V., Husar, J. D., and Wilson, W. E.: Formation and transport of secondary air-pollutants - ozone and aerosols in St-Louis urban plume, Science, 194, 187-189, https://doi.org/10.1126/science.959846, 1976.
Worden, J. R., Bloom, A. A., Pandey, S., Jiang, Z., Worden, H. M., Walker, T. W., Houweling, S., and Röckmann, T: Reduced biomass burning emissions reconcile conflicting estimates of the post-2006 atmospheric methane budget, Nat. Commun., 8, 2227, https://doi.org/10.1038/s41467-017-02246-0, 2017.

Xu, H., Wang, Y., and Wang, M., "The Performance of a ScaleAware Non-local PBL Scheme for the Sub-kilometer Simulation of a Deep CBL over the Taklimakan Desert," Adv. Meteorol., 2018, 8759594, https://doi.org/10.1155/2018/8759594, 2018. 